\title{
Synthesis and Physico-Chemical Properties in Aqueous Medium of All Possible Isomeric Bromo Analogues of Benzo- 1H-Triazole, Potential Inhibitors of Protein Kinases.
}

\begin{tabular}{|r|l|}
\hline Journal: & The Journal of Physical Chemistry \\
\hline Manuscript ID: & jp-2012-01561x.R2 \\
\hline Manuscript Type: & Article \\
\hline Date Submitted by the Author: & 22-May-2012 \\
\hline Complete List of Authors: & $\begin{array}{l}\text { Wasik, Romualda; Institute of Biochemistry and Biophysics PAS, } \\
\text { Wińska, Patrycja; Warsaw University of Technology, Faculty of Chemistry } \\
\text { Poznański, Jarosław; Institute of Biochemistry and Biophysics, Biophysics } \\
\text { Shugar, David; Institute of Biochemistry and Biophysics PAS, }\end{array}$ \\
\hline
\end{tabular}

SCHOLARONE ${ }^{m}$

Manuscripts 


\title{
Synthesis and Physico-Chemical Properties in
}

\section{Aqueous Medium of All Possible Isomeric Bromo}

\section{Analogues of Benzo-1H-Triazole, Potential Inhibitors of Protein Kinases.}

\author{
Romualda Wasik,,$^{\dagger}$ Patrycja Wińska, ${ }^{\dagger a}$ Jarosław Poznański, ${ }^{广^{*}}$ David Shugar 广t* $^{*}$ \\ $\dagger$ Institute of Biochemistry and Biophysics, Polish Academy of Sciences, Pawińskiego 5a, 02-106 \\ Warszawa, ${ }^{\ddagger}$ Division of Biophysics, Institute of Experimental Physics, University of Warsaw, Żwirki i \\ Wigury 93, 02-089 Warszawa, Poland \\ ${ }^{\mathrm{a} P r e s e n t}$ address: Faculty of Chemistry, Warsaw University of Technology, Noakowskiego 3, Warsaw, \\ Poland
}

\section{AUTHOR INFORMATION \\ Corresponding authors: \\ *E-mail: shugar@ibb.waw.pl (D.S.); jarek@ibb.waw.pl (J.P.)}




\begin{abstract}
In ongoing studies on the role of the individual bromine atoms of 4,5,6,7tetrabromobenzotriazole (TBBt) in its relatively selective inhibition of protein kinase CK2 $\alpha$, we have prepared all the possible two mono-, four di-, and two tri- bromobenzotriazoles, and determined their physico-chemical properties in aqueous medium. They exhibited a general trend of a decrease in solubility with an increase in the number of bromines on the benzene ring, significantly modulated by the pattern of substitution. For a given number of attached bromines, this was directly related to the electronic effects resulting from different sites of substitution, leading to marked variations of $\mathrm{pK}_{\mathrm{a}}$ values for dissociation of the triazole proton. Experimental data $\left(\mathrm{pK}_{\mathrm{a}}\right.$, solubility) and ab initio calculations demonstrated that hydration of halogenated benzotriazoles is driven by a subtle balance of hydrophobic and polar interactions. The combination of QM-derived free energies for solvation and proton dissociations was found to be a reasonably good predictor of inhibitory activity of halogenated benzotriazoles vs. CK2 $\alpha$. Since the pattern of halogenation of the benzene ring of benzotriazole has also been shown to be one of the determinants of inhibitory potency vs. some viruses and viral enzymes, the present comprehensive description of their physico-chemical properties should prove helpful in efforts to elucidate reaction mechanisms, including possible halogen bonding, and the search for more selective and potent inhibitors.
\end{abstract}




\section{INTRODUCTION}

The steadily increasing number of protein structures accessible in the PDB $(\sim 75,000)$ includes over 50,000 with bound ligands, thus providing a unique source of information on modes of interaction between proteins and their ligands. The initial pattern of such interactions, e.g. electrostatic, van der Waals (vdW) and hydrogen bonding, continues to be extended, e.g. to a $\mathrm{C}-\mathrm{H}$ group functioning as a hydrogen bond donor, and a $\pi$-electron system as a hydrogen bond acceptor.

The past decade has witnessed identification of many specific interactions between halogen atoms $(\mathrm{Cl}$, $\mathrm{Br}$, I) of halogenated ligands and the electron pairs of oxygen/nitrogen/sulfur. These interactions, analogous to that of a hydrogen bond, and now commonly referred to as halogen bonds, have been identified in many crystal structures of supramolecular ensembles, as well as in complexes between biomolecules and halogenated ligands. In both cases this is based in part on the observation that the distance between a halogen atom and its electron-donating partner is significantly lower than the sum of their vdW radii.

Bearing in mind that some natural, and an increasing number of synthetic, drug candidates are halogenated, ${ }^{1-3}$ understanding the nature and thermodynamics of halogen bonding should contribute to rational drug design. ${ }^{4}$ Halogenated compounds comprise a significant part of current screening libraries, and almost $20 \%$ of low-mass protein ligands listed in the PDB are halogenated (694 fluorinated listed in 919 PDB records, 992/1323 chlorinated, 281/518 brominated and 110/254 iodinated). ${ }^{5}$ Current widespread interest in elucidating the role of halogenated ligands in biological systems has been extensively reviewed, amongst others, by Voth $\& \mathrm{Ho}^{6}$, Parisini et al. ${ }^{7}$, Metrangolo et al. ${ }^{8,9}$

Despite the increasing number of crystal structures of complexes of proteins with halogenated ligands, only limited experimental data are available on intermolecular halogen bonding of molecules in solution. ${ }^{10-14}$ Temperature-dependent changes of infrared spectra recorded for mixtures of trifluorohalomethanes and trimethylamine (TMA) dissolved in liquidized noble gases (xenon, krypton, argon) enabled Hauchecorne et al. ${ }^{15}$ to estimate the enthalpy of formation of halogen bonded complexes as -6.8 , -4.4 and $-2.1 \mathrm{kcal} / \mathrm{mol}$ for TMA complexes with $\mathrm{CF}_{3} \mathrm{I}, \mathrm{CF}_{3} \mathrm{Br}$ and $\mathrm{CF}_{3} \mathrm{Cl}$, respectively, while the 
enthalpy of formation of $\mathrm{CF}_{3} \mathrm{H}-\mathrm{TMA}$ complexes in liquid argon and krypton was estimated as -3.5 $\mathrm{kcal} / \mathrm{mol},{ }^{16}$ hence between $\mathrm{CF}_{3} \mathrm{Br}$ and $\mathrm{CF}_{3} \mathrm{Cl}$. Moreover, in real systems, especially in aqueous medium, the entropic contribution to the free energy may significantly decrease the stability of halogen-bonded complexes, strongly supported by computational studies on potential halogen bonding interactions in solution, which showed that, at least for neutral systems, formation of halogen-bonding complexes is entropically disfavored. ${ }^{17}$ Furthermore, a water molecule was found to be a very weak halogen-bond acceptor in both polar and non-polar media, ${ }^{17}$ suggesting that the thermodynamics of solvation of halogenated compounds in aqueous medium is dominated by a balance of hydrophobic and electrostatic interactions.

Halogen bonding interactions were found responsible for ligand recognition in numerous protein structures deposited in the PDB. ${ }^{18}$ There are, however, only very limited data concerning halogen bonding with biomolecules in solution, and no consensus about the energetics involved. ${ }^{19-22}$ As demonstrated for halogenated protein ligands, contributions of enthalpic (e.g. electrostatic) and entropic (e.g., hydrophobic) interactions were virtually the same. ${ }^{23-26}$

Our interest in the foregoing stems from the finding that the first reported low-molecular weight potent, and relatively selective, inhibitor of the ubiquitous protein kinase CK2 (and its catalytic subunits $\mathrm{CK} 2 \alpha$ ) is 4,5,6,7-tetrabromobenzo-1H-triazole (TBBt, Scheme 1) ${ }^{27}$, a potential halogen bond donor. Subsequently, 4,5,6,7-tetrabromobenzoimidazole (TBBz) was found to be a comparably good inhibitor. $^{28}$ An even more potent one was recently reported, 4,5,6,7-tetrabromoindazole (compound K59). ${ }^{29}$

We have previously shown ${ }^{30}$ that replacement of one of the bromines of TBBt, that at $\mathrm{C}(5)$, by a variety of other substituents, differing in size, electronagativity and hydrophobicity, resulted in significant changes in ionic equilibrium, a protomeric preference for the neutral form, and inhibitory activity vs. human $\mathrm{CK} 2 \alpha$. The majority of these 5-substituted 4,6,7-tribromobenzotriazole derivatives displayed inhibitory activity comparable to that of TBBt, the most efficient amongst the 18 studied 
compounds. Overall, the hydrophobicity of the monoanionic form of the ligand appeared to be the principal factor governing its inhibitory activity.
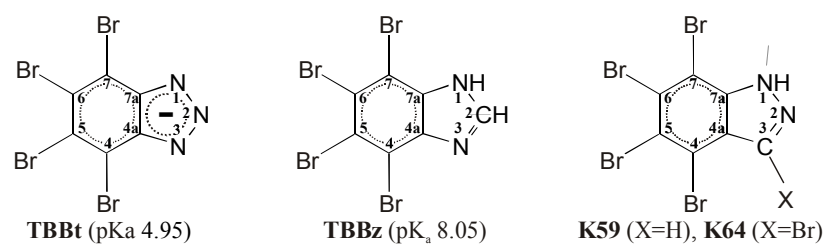

Scheme 1

Inspection of crystal structures of 4,5,6,7-tetrabromobenzotriazole (record 1J91, TBBt, also known as $\mathrm{TBB})^{27}$ and 4,5,6,7-tetrabromobenzoimidazole (2OXY, TBBz, compound $\left.\mathrm{K} 17\right){ }^{28}$ and 3,4,5,6,7pentabromoindazole $(3 \mathrm{KXG} \text {, compound } \mathrm{K} 64)^{29}$ (see Scheme 1) in complex with CK2 $\alpha$ reveals significant differences in their location in the CK2 $\alpha$ binding site, as well as in the topology of the intermolecular halogen bonds, see ref. 29 for detailed analysis. Furthermore, the binding mode of TBBt to $\mathrm{CDK} 2$, a close homolog of $\mathrm{CK} 2 \alpha$, resembles that of $\mathrm{TBBz}$, but not $\mathrm{TBBt}$, in complex with CK2a, including ligand orientation and two side-chain carbonyls involved in halogen bonding. ${ }^{31}$ These differences clearly indicate that binding of a halogenated ligand, at least to CK2 $\alpha$, is driven by a balance of electrostatic, hydrophobic, hydrogen-bonding and halogen-bonding interactions, with the electrostatic component being predominant, supported also by analysis of the structure-activity relations for a series of 5-substituted 4,6,7-tribromobenzotriazoles, ${ }^{30}$ (see above). The majority of these displayed $\mathrm{IC}_{50}$ values comparable to that of TBBT, but, generalizing, demonstrated that hydrophobic interactions, corrected for dissociation of the triazole proton in aqueous medium, predominate in stabilization of the proteinligand complexes. The results also indicated that eventual contribution of halogen bonding to the final free energy of complex formation is at least one order of magnitude lower than that of hydrophobic interactions. It should however be noted that, for the analyzed compounds, there is a strong correlation between the number of halogen atoms and hydrophobic contribution to the free energy of ligand binding. ${ }^{30}$ 
To further clarify this, and to better define the role of the individual $\mathrm{Br}$ atoms of $\mathrm{TBBt}$, as regards potency of inhibition of $\mathrm{CK} 2 \alpha$, as well as to describe the thermodynamics of potential CK2a inhibitors in aqueous medium, we have prepared the two mono-, the four di-, and the two tri- bromobenzotriazoles to provide, in addition to $\mathrm{TBBt}$, the 9 possible halogenation patterns of the benzene ring in benzotriazole, and to determine their physico-chemical properties, including aqueous solubility and protonation equilibria, previously shown to be relevant to inhibitory activity against human CK2 $\alpha^{30,32}$

Furthermore, bearing in mind that the pattern of halogenation of benzotriazoles (and benzimidazoles) has been shown to modulate their inhibitory activities vs. some viruses and viral enzymes, ${ }^{33-35}$ the present data should prove helpful in elucidation of the mechanisms involved.

\section{EXPERIMENTAL SECTION}

There are no reports on direct bromination of benzotriazole, with the exception of $\mathrm{TBBt}^{36}$ Preparation of bromo isomers of benzotriazole was carried out using different methods, including bromination of 2,1,3-benzothiadiazoles $^{37}$ or nitro analogues of aniline. ${ }^{38,39}$ The 4,5,6tribromobenzotriazole analogue was synthesized by nitration of the appropriate bromo analogue of benzene, whereas 4,5,7-tribromobenzotriazole $\left(4,5,7-\mathbf{B r}_{3} \mathbf{B t}\right)$ was obtained by decarboxylation in quinoline of parent 5-carboxy-4,5,7-tribromobenzotriazole. ${ }^{30}$

General. Starting materials: $o$-phenylenediamine (1), 2,4-dibromo-6-nitroaniline (7) and 1,2,3-tribromo5-nitrobenzene (9) were from commercial sources (Aldrich), and were used without additional purification. The intermediate crude diamines, $\mathbf{6 b}, \mathbf{7 b}$, were used without further characterization.

Melting points (uncorr.) were determined in open capillary tubes, using a Büchi apparatus B504. UV absorption spectra were recorded on a Specord 200 instrument. Mass spectrometry was performed with a Micro-mass LTQ FT Ultra spectrometer. ${ }^{1} \mathrm{H}$ and ${ }^{13} \mathrm{C}$ NMR spectra were recorded in $\mathrm{CDCl}_{3}$ (benzothiadiazoles) or DMSO- $d_{6}$ (benzotriazoles) on an Inova 500 instrument. Spectra were analyzed with the aid of the MestRe-C (version 2.3a) program (see below). ${ }^{40}$ Chemical shifts are in ppm relative to tetramethylsilane $\left(\mathrm{Me}_{4} \mathrm{Si}, \delta=0\right)$. 
All compounds were checked by thin-layer chromatography (TLC) on $0.2 \mathrm{~mm}$ Merck silica gel $60 \mathrm{~F}_{254}$ plates. Preparative separations were carried out by column chromatography, using Merck silica gel (230$400 \mathrm{mesh}$ ), or on preparative glass plates $\left(2 \mathrm{~mm}\right.$, Merck silica gel $\left.60 \mathrm{~F}_{254}\right)$, using the following solvent systems: (A) $\mathrm{CHCl}_{3}: \mathrm{MeOH}$ (9:1), (B) EtOAc: n-heptan: AcOH (2:2:0.2), (C) $\mathrm{CHCl}_{3}$.

NMR Spectroscopy. ${ }^{1} \mathrm{H}$ and ${ }^{13} \mathrm{C}$ NMR spectra were recorded at $298 \mathrm{~K}$ on a $500 \mathrm{MHz}$ Varian spectrometer for DMSO solutions of the ligands at concentrations, depending on solubility, in the range $100 \mu \mathrm{M}$ to $1 \mathrm{mM}$. All spectra were processed and analyzed with the aid of MestRec (version $2.3 \mathrm{a}) .{ }^{40}{ }^{1} \mathrm{H}$ spectra were recorded in the range $0-10 \mathrm{ppm}(24 \mathrm{~K}$ data points) and processed using $\pi / 3$-shifted squared sine-bell and zero-filling up to $32 \mathrm{~K}$ data points prior to Fourier transformation. ${ }^{13} \mathrm{C}$ spectra, recorded with broadband proton decoupling in the range 0-200 ppm and $32 \mathrm{~K}$ data points, were processed using Lorenzian filtering, resulting in $15 \mathrm{~Hz}$ resonance broadening followed by a $\pi / 2$-shifted squared sine-bell. The DMSO signal ( ${ }^{1} \mathrm{H}$ quintuplet at $2.50 \mathrm{ppm},{ }^{13} \mathrm{C}$ septuplet at $29.43 \mathrm{ppm}$ ) was used as the internal reference. Assignments for ${ }^{1} \mathrm{H}$ resonances were done on the basis of line splitting patterns caused by homonuclear scalar coupling, while ${ }^{13} \mathrm{C}$ resonance assignments were supported by GIAO-derived NMR shielding parameters ( $c f$. Supplementary Figure 1 for general correlation)

UV-monitored titration. Titration of the ligands in the $\mathrm{pH}$ range $2-12$ was followed at $298 \mathrm{~K}$ on a Specord 200 UV-VIS spectrometer equipped with a thermostated cell holder. Changes in absorption were globally analyzed using the Henderson Hasselbach formula:

$$
\varepsilon(\lambda, p H)=\frac{\varepsilon_{n}(\lambda) \cdot 10^{p H}+\varepsilon_{a}(\lambda) \cdot 10^{p K_{a}}}{10^{p H}+10^{p K_{a}}}
$$

where $\varepsilon(\lambda, \mathrm{pH})$ is the spectrum recorded at a given $\mathrm{pH}$, and $\varepsilon_{\mathrm{n}}(\lambda), \varepsilon_{\mathrm{a}}(\lambda)$ are the reference spectra for the neutral and dissociated forms. The $\mathrm{pK}_{\mathrm{a}}$ values were then estimated using the Marquardt-Levenberg algorithm $^{41}$ implemented in the Gnuplot program. ${ }^{42}$

Solubility. Aqueous solubilities of benzotriazole analogues were determined in buffered solution at $\mathrm{pH}$ 7.5. The suspensions were shaken at $25^{\circ} \mathrm{C}$ in a shaker (Eppendorf Termomixer Comfort) for $96 \mathrm{~h}$, and 
then centrifuged. The concentration of clear supernatant was estimated from the spectra recorded in the range $220-300 \mathrm{~nm}$

\section{Synthetic procedures}

2,1,3-Benzothiadiazole (2). To a suspension of $30 \mathrm{~g}(0.28 \mathrm{~mol})$ of $o$-phenylenediamine (1) in dry toluene $(300 \mathrm{~mL})$ was added $90 \mathrm{~mL}(1.23 \mathrm{~mol})$ of thionyl chloride. The mixture was heated under reflux for 3 hours, followed by addition of $65 \mathrm{~mL}$ thionyl chloride and $6 \mathrm{~mL}$ dry pyridine in 3 portions of $2 \mathrm{~mL}$ each. Heating was continued for an additional 19 hours. Distillation at $150{ }^{\circ} \mathrm{C}$ removed toluene and excess thionyl chloride. The fraction boiling at $200-220^{\circ} \mathrm{C}$ was collected and, on cooling, the distillate of 2,1,3-benzothiadiazole solidified. The product was dissolved in ethanol, reprecipitated with water, collected and washed with water to yield $31.2 \mathrm{~g}(82 \%)$ of $2: \mathrm{mp} 43.2-44.1{ }^{\circ} \mathrm{C}\left[\right.$ lit. $\left.44{ }^{\circ} \mathrm{C}^{37}\right)$; $\mathrm{R}_{\mathrm{f}}(\mathrm{C}) 0.74$; ${ }^{1} \mathrm{H}$ NMR: $\delta$ [ppm]: 8.01 (dd, 2H, $\left.J=3.4,6.8 \mathrm{~Hz}, \mathrm{H}-4, \mathrm{H}-7\right) ; 7.6(\mathrm{dd}, 2 \mathrm{H}, J=2.9 \mathrm{~Hz}, 6.8 \mathrm{~Hz}, \mathrm{H}-5, \mathrm{H}-6)$.

4-Bromo-2,1,3-benzothiadiazole (3a). $5 \mathrm{~g}$ (37 mmol) of 2,1,3-benzothiadiazole (2) was suspended in $10 \mathrm{~mL}$ of $47 \% \mathrm{HBr}$. The mixture was heated to reflux with stirring, and $1.9 \mathrm{~mL}$ (37 mmol) of $\mathrm{Br}_{2}$ added portionwise for $2 \mathrm{~h}$. Heating was continued for 1 hour. The mixture was cooled, poured into ice water, and the resulting precipitate collected by filtration. The crude product included small amounts of starting material and 4,7-dibromo-2,1,3-benzothiadiazole (4a), which were removed by steam distillation. Crystallization from EtOH gave $4.34 \mathrm{~g}(55 \%)$ of pure product $3 \mathrm{a}: \mathrm{mp} 80.1-81.7^{\circ} \mathrm{C}\left[\mathrm{lit} .80-81{ }^{\circ} \mathrm{C}{ }^{37}\right] ; \mathrm{R}_{\mathrm{f}}$ (C) $0.80 ;{ }^{1} \mathrm{H}$ NMR: $\delta[\mathrm{ppm}]: 7.98(\mathrm{dd}, 1 \mathrm{H}, J=0.73 \mathrm{~Hz}, 8.79 \mathrm{~Hz}, \mathrm{H}-5) ; 7.85(\mathrm{dd}, 1 \mathrm{H}, J=0.73 \mathrm{~Hz}, 7.08$ Hz, H-7); 7.48 (dd 1H $J=8.79 \mathrm{~Hz}, 7.08 \mathrm{~Hz}, \mathrm{H}-6$ ).

4-Bromobenzotriazole (3c, 4-BrBt). $150 \mathrm{mg}(0.7 \mathrm{mmol})$ of 4-bromo-2,1,3-benzothiadiazole (3a) was ground in a mortar with $660 \mathrm{mg}(3.48 \mathrm{mmol})$ of $\mathrm{SnCl}_{2}$. and added gradually to $10 \mathrm{~mL}$ conc. $\mathrm{HCl}$. The mixture was stirred for 2 hours at room temperature, and the resulting white solid filtered off and suspended in $25 \%$ aqueous $\mathrm{NaOH}$. Ether extraction $(2 \times 50 \mathrm{~mL})$, drying the ether layer over anhydrous $\mathrm{Na}_{2} \mathrm{SO}_{4}$, and concentration in vacuo afforded $105 \mathrm{mg}(81 \%)$ of 3-bromo-o-phenylenediamine $(\mathbf{3 b}) .{ }^{1} \mathrm{H}$ 
NMR 500MHz (DMSO-d $\left.)_{6}\right) \delta[p p m]: 10$ (s, ext. br, $\mathrm{NH}_{2}$ x 2), 7.43 (dd, 1H, $J=1.3 \mathrm{~Hz}, J=7.9 \mathrm{~Hz}, \mathrm{H}-$ 5), $7.28(\mathrm{dd}, 1 \mathrm{H}, J=1.3 \mathrm{~Hz}, J=7.9 \mathrm{~Hz}, \mathrm{H}-7), 6.62$ (t, 1H, $J=7.9 \mathrm{~Hz}, \mathrm{H}-6)$;

(a) A solution of $80 \mathrm{mg}(0.43 \mathrm{mmol})$ of 3-bromo-o-phenylenediamine $(\mathbf{3 b})$ in $1 \mathrm{~mL} \mathrm{AcOH}$ and 0.4 $\mathrm{mL} \mathrm{H}_{2} \mathrm{O}$ was cooled to $0{ }^{\circ} \mathrm{C}$, followed by addition of $48.9 \mathrm{mg}(0.71 \mathrm{mmol})$ of sodium nitrite in $0.3 \mathrm{~mL}$ water. The mixture was stirred for 1 hour at room temperature, and the resulting precipitate collected by filtration and recrystallized from dilute ethanol to give $70 \mathrm{mg}(83 \%)$ of pure product $\mathbf{3 c}$.

(b) $0.5 \mathrm{~g}$ (1.9 $\mathrm{mmol})$ of the dihydrochloride of 3-bromo-o-phenylenediamine (3b) was dissolved in 10 $\mathrm{mL}$ water, $0.5 \mathrm{~mL}$ conc. $\mathrm{HCl}$, and $5 \mathrm{~mL}$ EtOH. The solution was cooled to $0{ }^{\circ} \mathrm{C}$ and $220 \mathrm{mg}(3.1 \mathrm{mmol})$ sodium nitrite in $2 \mathrm{~mL}$ water was added all at once. The mixture was stirred for 1 hour at room temperature, and the resulting precipitate collected by filtration and recrystallized from dilute ethanol to give $240 \mathrm{mg}(63 \%)$ of pure product $3 \mathrm{c}: \mathrm{mp} 183.5-185.5{ }^{\circ} \mathrm{C} ; \operatorname{Rf}(\mathrm{A}) 0.63,(\mathrm{~B}) 0.69 ; \mathrm{UV} \lambda_{\max }(\varepsilon):(\mathrm{pH} 2)$ $267.5 \mathrm{~nm}$ (8465); (pH 7) $272 \mathrm{~nm}$ (8660); (pH 12) $280 \mathrm{~nm}$ (10350); ${ }^{1} \mathrm{H}$ NMR $\delta: 16.13$ (br s, 1H-NH), 7.89 (br s, 1H, H-5), 7.67 (d, 1H, $J=6.6 \mathrm{~Hz}, \mathrm{H}-7), 7.4(\mathrm{t}, 1 \mathrm{H}, J=7.7 \mathrm{~Hz}, \mathrm{H}-6) ;{ }^{13} \mathrm{C} \mathrm{NMR} \delta: 140.79$, 138.03, 128. 30, 128.45, 113.88, 109.13; MS for $\mathrm{C}_{6} \mathrm{H}_{5} \mathrm{Br}_{1} \mathrm{~N}_{3}[\mathrm{M}+\mathrm{H}]^{+}$: found, 197.96629, calcd. 197.96668.

4,7-Dibromo-2,1,3-benzothiadiazole (4a). $5 \mathrm{~g}(37 \mathrm{mmol})$ of 2,1,3-benzothiadiazole (2) was suspended in $15 \mathrm{~mL} 47 \% \mathrm{HBr}$. The mixture was heated under reflux with stirring, and $5.65 \mathrm{~mL}(110$ mmol) $\mathrm{Br}_{2}$ added dropwise very slowly ( $\sim 3$ hours). The mixture was then heated for another 2 hours and the residue collected by filtration. Recrystallization from $\mathrm{AcOH}$ with addition of EtOH, and then from EtOH, gave $7.02 \mathrm{~g}(65 \%)$ of pure product $4 \mathrm{a}: \mathrm{mp} .188 .4-189.5{ }^{\circ} \mathrm{C}\left[\right.$ lit. $\left.188-189{ }^{\circ} \mathrm{C}{ }^{37}\right]$; $\mathrm{R}_{\mathrm{f}}(\mathrm{C}) 0.85 ;{ }^{1} \mathrm{H}$ NMR : $\delta[p p m]: 7.73(\mathrm{~s}, 2 \mathrm{H}, \mathrm{H}-5, \mathrm{H}-6)$.

4,7-Dibromobenzotriazole (4c, 4,7-Br 2 Bt). 2 g (6.83 mmol) of 4,7-dibromo-2,1,3-benzothiadiazole (4a) was dissolved in $108 \mathrm{~mL}$ THF and $40 \mathrm{~mL}$ EtOH. The mixture was cooled to $0{ }^{\circ} \mathrm{C}$ and $4.4 \mathrm{~g}(116$ mmol) cooled $\mathrm{NaBH}_{4}$ was added portionwise. The mixture was then stirred for 20 hours. Following removal of solvent, $\mathrm{H}_{2} \mathrm{O}$ was added and the mixture extracted with diethyl ether. The organic phase was 
washed with brine and dried over $\mathrm{Na}_{2} \mathrm{SO}_{4}$. Evaporation in vacuo gave $80 \%$ yield of the diamine $4 \mathbf{b}:{ }^{1} \mathrm{H}$ NMR 500MHz (DMSO-d $\left.)_{6}\right) \delta[p p m]: 6.64(\mathrm{~s}, 2 \mathrm{H}), 5.00\left(\mathrm{~s}, 4 \mathrm{H}, \mathrm{NH}_{2}\right)$, which was then used to obtain 4,7-dibromobenzotriazole (4c) by the same procedure as for 4-bromobenzotriazole (3c, see above), in 75 \% yield: mp 255.5-257.1 (dec.); $\mathrm{R}_{\mathrm{f}}$ (A) 0.6, (B) 0.82; UV $\lambda_{\max }(\varepsilon):(\mathrm{pH} 2) 275 \mathrm{~nm}(9140), 292 \mathrm{~nm}$ (8260); (pH 7) 286 nm (11810); (pH 12) 285 nm (12621); ${ }^{1} \mathrm{H}$ NMR $\delta: 16.64$ (br s, NH), 7.63 (s, 2H, H5, H-6). ${ }^{13} \mathrm{C}$ NMR $\delta: 139.80,129.93,107.26$; MS for $\mathrm{C}_{6} \mathrm{H}_{4} \mathrm{Br}_{2} \mathrm{~N}_{3}[\mathrm{M}+\mathrm{H}]^{+}$: found, 277.87412, calcd. 277.87515 .

5-Bromo-2,1,3-benzothiadiazole (5a). To a suspension of $8 \mathrm{~g}(0.03 \mathrm{~mol})$ of 4-Br-1,2phenylenediamine $\mathbf{( 5 \mathbf { b } )}$ dihydrochloride in dry toluene $(70 \mathrm{~mL})$ was added $10 \mathrm{~mL}(0.14 \mathrm{~mol})$ of thionyl chloride. The mixture was heated under reflux for $1 \mathrm{~h}$, followed by addition of $5 \mathrm{~mL}$ thionyl chloride and $2 \mathrm{~mL}$ dry pyridine. Heating was continued for an additional $19 \mathrm{~h}$. All fractions boiling to $150{ }^{\circ} \mathrm{C}$ were collected. Steam distillation of the residue, and recrystallisation of the product from EtOH/water, afforded 5-bromo-2,1,3-benzothiadiazole (5a) in $70 \%$ yield: mp 59.1-60.3 ${ }^{\circ} \mathrm{C}$ [lit. 59-61 ${ }^{\circ} \mathrm{C}{ }^{37}$ ]; $\mathrm{R}_{\mathrm{f}}(\mathrm{C})$ 0.85; ${ }^{1} \mathrm{H}$ NMR: $\delta$ [ppm]: $8.23(\mathrm{dd}, 1 \mathrm{H}, J=0.61 \mathrm{~Hz}, 1.83 \mathrm{~Hz}, \mathrm{H}-4) ; 7.88(\mathrm{dd}, 1 \mathrm{H}, J=0.61 \mathrm{~Hz}, 9.28 \mathrm{~Hz}$, H-7); 7.68 (dd 1H J=1.83 Hz, 9.28 Hz, H-6).

4,5-Dibromo-2,1,3-benzothiadiazole (6a). To a solution of $500 \mathrm{mg}(2.65 \mathrm{mmol})$ of 5-bromo-2,1,3benzothiadiazole (5a) in $4 \mathrm{~mL}$ boiling $\mathrm{HBr}$ was added $140 \mu \mathrm{L}(2.7 \mathrm{mmol})$ of $\mathrm{Br}_{2}$ in 3 portions within 3 hours, and heating continued for $18 \mathrm{~h}$. The reaction mixture was poured into ice water, filtered, washed with hot water and dried. Purification by silica gel column chromatography with chloroform (stab./ amylene) and recrystallization from $\mathrm{MeOH}$ gave $579 \mathrm{mg}$ (66 \%) of pure 4,5-dibromo-2,1,3benzothiadiazole (6a): $\mathrm{mp} 133.3-134.7^{\circ} \mathrm{C}\left[\right.$ lit. $\left.134-136{ }^{\circ} \mathrm{C}{ }^{37}\right] ;{ }^{1} \mathrm{H}$ NMR $\delta: 7.84,7.8$ (as. $\mathrm{d}, 2 \mathrm{H}, J=9.19$ Hz, H-5, H-6).

4,5-Dibromobenzotriazole $\left(6 \mathbf{c}, 4,5-\mathrm{Br}_{2} \mathrm{Bt}\right)$. To a cooled $\left(-5^{\circ} \mathrm{C}\right)$ suspension of $150 \mathrm{mg}(0.51 \mathrm{mmol})$ of 4,5-dibromo-2,1,3-benzothiadiazole (6a) in $10 \mathrm{~mL}$ EtOH, was added, portionwise, $334 \mathrm{mg}(8.82 \mathrm{mmol})$ of $\mathrm{NaBH}_{4}$ at $-5^{\circ} \mathrm{C}$ and the mixture stirred for $21 \mathrm{~h}$ at room temperature. Following evaporation in vacuo, 
$\mathrm{H}_{2} \mathrm{O}$ was added and the mixture extracted with diethyl ether. The organic layer was washed with water and dried over anhydrous sodium sulfate. Evaporation of solvent gave $107 \mathrm{mg}(79 \%)$ of the crude diamine $\mathbf{6 b}$, which was used to obtained 4,5-dibromobenzotriazole (6c) by the same procedure as for 4bromobenzotriazole (3c, see above), in $70 \%$ yield: $\mathrm{mp} .265^{\circ} \mathrm{C}(\mathrm{dec}) ; \mathrm{R}_{\mathrm{f}}(\mathrm{A}) 0.64,(\mathrm{~B}) 0.71 ; \mathrm{UV} \lambda_{\max }(\varepsilon)$ : (pH 2) 273 nm (8370); (pH 7) 285 nm (9865); (pH 12) 285 nm (11000); ${ }^{1} \mathrm{H}$ NMR $\delta: 16.22$ (s, NH), 7.87 (d, 1H, $J=8.7 \mathrm{~Hz}, \mathrm{H}-6), 7.74(\mathrm{~d}, 1 \mathrm{H}, J=8.7 \mathrm{~Hz}, \mathrm{H}-7) ;{ }^{13} \mathrm{C}$ NMR $\delta: 142.04,137.49,131.26,121.44$, 115.52, 111.3; MS for $\mathrm{C}_{6} \mathrm{H}_{4} \mathrm{Br}_{2} \mathrm{~N}_{3}[\mathrm{M}+\mathrm{H}]^{+}$: found, 277.87407, calcd. 277.87515.

4,6-Dibromobenzotriazole (7c, 4,6-Br 2 Bt). To a stirred solution of $1.5 \mathrm{~g}$ (5 mmol) of 2,4-dibromo-6nitroaniline (7) in a mixture of $15 \mathrm{~mL}$ ethyl acetate and $7 \mathrm{~mL}$ EtOH was added, at ambient temperature, $4.86 \mathrm{~g}(25 \mathrm{mmol}) \mathrm{SnCl}_{2}$. The mixture was refluxed for 2 hours, solvent removed in vacuo, the residue basified with $2 \mathrm{~N} \mathrm{NaOH}$, and extracted with diethyl ether. The extract was washed with brine, dried over $\mathrm{Na}_{2} \mathrm{SO}_{4}$ and evaporated. The residue was dissolved in $\mathrm{n}$-hexane/EtOH $(2: 1)$, and conc. $\mathrm{HCl}$ /isopropanol (1:5) added. The resulting precipitate was filtered off, and washed with n-hexane to give $\lg (59 \%)$ of the crude dihydrochloride of 3,5-Dibromo- $o$-phenylenediamine (7b), which was then used to obtained 4,6-dibromobenzotriazole (7c) by the same procedure as for 4-bromobenzotriazole, in 79 \% yield: mp 276.2-278.7 ${ }^{\circ} \mathrm{C}$ [lit. $288-290{ }^{\circ} \mathrm{C}{ }^{43}$ ]; $\mathrm{R}_{\mathrm{f}}(\mathrm{A}) 0.66,(\mathrm{~B}) 0.77$; UV $\lambda_{\max }(\varepsilon):(\mathrm{pH} 2) 275 \mathrm{~nm}$ (8500); (pH 7) 284 nm (8950); (pH 12) 285 nm (9645). ${ }^{1} \mathrm{H}$ NMR $\delta: 16.32$ (br s, NH), 8.2 (s, 1H, H-7), $7.87(\mathrm{~s}, 1 \mathrm{H}, \mathrm{H}-4) ;{ }^{13} \mathrm{C}$ NMR $\delta: 140.74,138.73,130.7,119.85,116.67,110.92 ; \mathrm{MS}$ for $\mathrm{C}_{6} \mathrm{H}_{4} \mathrm{Br}_{2} \mathrm{~N}_{3}$ $[\mathrm{M}+\mathrm{H}]^{+}$: found, 277.87409, calcd. 277.87515 .

5,6-Dibromobenzotriazole $\left(\mathbf{8 c}, \mathbf{5 , 6 - B r} \mathbf{B}_{2} \mathbf{B t}\right)$. This compound was obtained as for 4bromobenzotriazole, from 4,5-dibromo-o-phenylenediamine (8b) according to a previous procedure, ${ }^{44}$ $\mathrm{mp} 261{ }^{\circ} \mathrm{C}(\mathrm{dec}) ; \mathrm{R}_{\mathrm{f}}(\mathrm{A}) 0.64$, (B) 0.75; UV $\lambda_{\max }(\varepsilon):(\mathrm{pH} 2) 296 \mathrm{~nm}(5700), 276 \mathrm{~nm}(5340)$; (pH7) 294 nm (7630); (pH 12) 293 nm (9340); ${ }^{1} \mathrm{H}$ NMR $\delta: 8.44$ (s, 2H, H-4, H-7); ${ }^{13} \mathrm{C}$ NMR $\delta: 139.2,120.74$, 119.84. MS for $\mathrm{C}_{6} \mathrm{H}_{4} \mathrm{Br}_{2} \mathrm{~N}_{3}[\mathrm{M}+\mathrm{H}]^{+}$: found, 277.87406, calcd. 277.87515 . 
1,2,3-Tribromo-5,6-dintrobenzene (9a). A mixture of $0.5 \mathrm{~g}$ (1.4 mmol) of 1,2,3-tribromo-5nitrobenzene (9) in $2 \mathrm{~mL}$ fuming nitric acid and $0.5 \mathrm{~mL}$ conc. sulphuric acid was heated at $100{ }^{\circ} \mathrm{C}$ for 5 h. After cooling, the product was poured into a large quantity of cold water. The resulting precipitate was collected by filtration and washed with water. The yield of 9a was quantitative; mp $161-162.3{ }^{\circ} \mathrm{C}$ [lit. $160{ }^{\circ} \mathrm{C}{ }^{45}$ ]; ${ }^{1} \mathrm{H}$ NMR $500 \mathrm{MHz}$ (DMSO) $\delta: 8.8$ (s, 1H, H-6); ${ }^{13} \mathrm{C}$ NMR $500 \mathrm{MHz}$ (DMSO) $\delta: 143.15$, 138.64, 137.43, 129.4, 128.5, 120.01.

4,5,6-Tribromobenzotriazole $\left(9 \mathrm{c}, 4,5,6-\mathbf{B r}_{3} \mathbf{B t}\right) .300 \mathrm{mg}(0.741 \mathrm{mmol})$ of 1,2,3-tribromo-4,5dinitrobenzene (9a) was ground in a mortar with $1.4 \mathrm{~g}(7.41 \mathrm{mmol})$ of $\mathrm{SnCl}_{2}$ and added gradually, within $1.5 \mathrm{~h}$, to $10 \mathrm{~mL}$ of conc. $\mathrm{HCl}$ at $80{ }^{\circ} \mathrm{C}$. The resulting precipitate was collected and basified with $2 \mathrm{~N} \mathrm{NaOH}$ to give $225 \mathrm{mg}(82 \%)$ of pure 3,4,5-tribromo-1,2-diaminobenzene (9b): ${ }^{1} \mathrm{H}$ NMR $500 \mathrm{MHz}$ $\left(\mathrm{DMSO}_{-} \mathrm{d}_{6}\right) \delta: 6.88(\mathrm{~s}, 1 \mathrm{H}), 5.26\left(\mathrm{~s}, 2 \mathrm{H}-\mathrm{NH}_{2}\right), 5.1\left(\mathrm{~s}, 2 \mathrm{H}-\mathrm{NH}_{2}\right)$. This was used to obtain 4,5,6tribromobenzotriazole $(9 \mathrm{c})$ as for 4-bromobenzotriazole, in $83 \%$ yield; mp $301-304{ }^{\circ} \mathrm{C}$; UV $\lambda_{\max }(\varepsilon)$ : (pH 7) 286 nm (11810); (pH 12) 285 nm (12620); ${ }^{1} \mathrm{H}$ NMR $\delta: 8.45$ (s, 1H, H-7), 16.44 (br s, NH); ${ }^{13} \mathrm{C}$ NMR $\delta: 141.57,137.86,124.15,122.47,118.76,113.19$. MS for $\mathrm{C}_{6} \mathrm{H}_{4} \mathrm{Br}_{2} \mathrm{~N}_{3}[\mathrm{M}+\mathrm{H}]^{+}$: found, 355.78447, calcd. 355.78566 .

QM Methods. Ab initio calculations were performed for the neutral derivatives in their three possible protonation states, $\mathrm{N}(1)-\mathrm{H}, \mathrm{N}(2)-\mathrm{H}, \mathrm{N}(3)-\mathrm{H}$ (Scheme 2), and for the monoanionic forms with the aid of Firefly (PC GAMESS) version 7.1. ${ }^{46}$ Initial coordinates of TBBt were adopted from its crystal structure in a complex with maize $\mathrm{CK} 2 \alpha,{ }^{47}$ while the structures of other halogenated Bt derivatives were built by subsequent replacement of bromine atoms in TBBt by hydrogens. All structures were preoptimized, using the semiempirical PM3 method, and then analyzed using the DFT B3LYP/6-31G(d,p) method, previously found adequate for modeling of benzotriazole derivatives. ${ }^{30,32}$ Corrections for solute-solvent interactions were estimated using the Polarizable Continuum Model (PCM). ${ }^{48}$ Zero-point energies, and thermal corrections for translational, rotational and vibrational degrees of freedom, were used to convert internal energies to Gibbs free energies at 298.15 K. ESP charges, calculated for optimized molecules, were then used in Molecular Mechanics calculations to parameterize electrostatic interactions. 


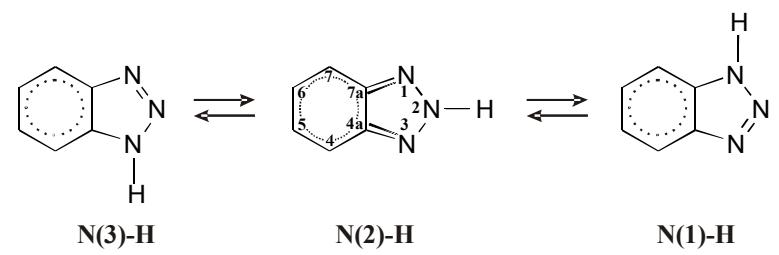

Scheme 2

Differences in free energy were analyzed for: (a) dissociation of the triazole N-H proton $\left(\Delta \mathrm{G}_{\text {diss }}\right),(\mathrm{b})$ solvation $\left(\Delta \mathrm{G}_{\text {solv }}\right)$, and (c) protomeric equilibria for the neutral forms shown in Scheme $2\left(\Delta \mathrm{G}_{1}, \Delta \mathrm{G}_{2}\right.$, $\Delta \mathrm{G}_{3}$ ), according to the following formulae:

$$
\begin{aligned}
& \Delta G_{\text {diss }}=G_{\text {solv }}(\text { monoanion })-G_{\text {solv }}(\text { neutral })+G_{\text {hydr }}\left(H^{+}\right) \\
& \Delta G_{\text {solv }}=G_{\text {solv }}-G_{0} \\
& G_{\text {solv }}=E_{\text {elec }}+G_{r e p}+G_{\text {disp }}+E_{\text {cav }}+E_{z p}+G_{\text {trans }}+G_{r o t}+G_{v i b} \\
& \Delta G_{i}=G_{\text {solv }}(\text { state } \cdot i)-\min _{j=1,2,3}\left(G_{\text {solv }}(\text { state } \cdot j)\right)
\end{aligned}
$$

where $\mathrm{G}_{0}$ is the QM-derived Gibbs free energy in vacuo, and the free energy of proton hydration, $\mathrm{G}_{\text {hydr }}\left(\mathrm{H}^{+}\right)$, was taken as $-262.3 \mathrm{kcal} / \mathrm{mol}^{49}$ Molecular volumes were calculated according to the algorithm of tessellation implemented in the GEPOL package. ${ }^{50}$

\section{RESULTS AND DISCUSSION}

Synthetic procedures. 4-bromobenzotriazole (3c) and 4,7-dibromobenzotriazole (4c) (Scheme 3) were obtained via direct bromination with $\mathrm{Br}_{2}$ of 2,1,3-benzothiadiazole (2) in $47 \% \mathrm{HBr}^{37}$ The molar ratio of bromine to 2 was 1:1 for 4-bromobenzothiadiazole, and 3:1 for the 4,7-dibromo analogue.

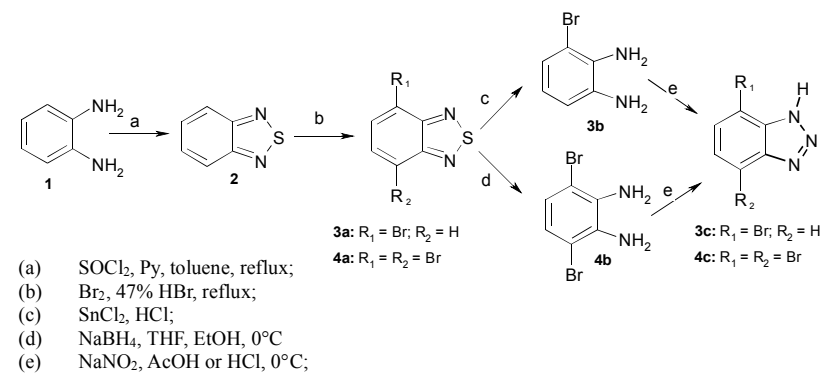

Scheme 3 
The sulfur extrusion reaction was performed by two different methods, depending on the number of bromine atoms. Reduction of 4-bromobenzothiadiazole (3a) to 3-bromo-o-phenylenediamine (3b) made use of $\mathrm{SnCl}_{2} / \mathrm{HCl}^{51}$ whereas 4,7-dibromobenzothiadiazole (4a) was reduced with $\mathrm{NaBH}_{4}$ in THF/ethanol. It should be noted that ring opening of 4,7-dibromobenzothiadiazole (4a) in EtOH at $0{ }^{\circ} \mathrm{C}^{52}$ virtually did not proceed, even with long reaction times, but the presence of THF gave the product in $80 \%$ yield. Ring closure of $\mathbf{3 b}$ and $\mathbf{4 b}$ with $\mathrm{NaNO}_{2}$ in $\mathrm{HCl}$ or $\mathrm{AcOH}$ led to 4bromobenzotriazole (3c) and 4,7-dibromobenzotriazole (4c), respectively, in relatively good yields

The starting compound for synthesis of 3,4-dibromobenzotriazole (6c) was 4-Br-1,2-

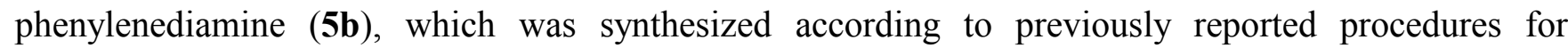
bromination of 2-nitroaniline with N-bromosuccinimide (NBS) to 4-bromo-2-nitroaniline, ${ }^{38}$ followed by reduction with $\mathrm{SnCl}_{2}$ in ethanol. Ring closure of the dihydrochloride $\mathbf{5 b}$ with thionyl chloride in the presence of pyridine gave 5-bromo-2,1,3-benzothiadiazole (5a) in $70 \%$ yield. On the other hand, ring closure by nitrous-acid-promoted cyclization of $\mathbf{5 b}$ was previously shown to lead to 5bromobenzotriazole (5c) (Scheme 4). Direct bromination of 5a gave 4,5-dibromobenzothiadiazole (6a) in $66 \%$ yield.

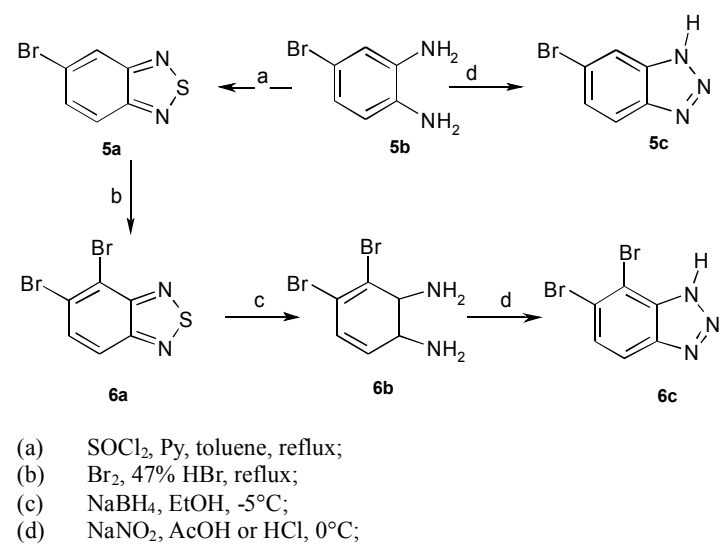

Scheme 4

Sulfur extrusion, leading to $\mathbf{6 b}$, was carried out as for $\mathbf{4 c}$ with $\mathrm{NaBH}_{4}$, but without presence of $\mathrm{THF}$, in $79 \%$ yield. It should be recalled (see above) that rapid reduction of $\mathbf{3 a}$ was obtained by using $\mathrm{SnCl}_{2}$ as reducing agent. But reduction of dibromo analogues under these conditions can lead to removal of one 
atom of bromine. 3,4-dibromo-o-phenylenediamine (6b), in nitrous acid-promoted cyclization, gave 4,5dibromobenzotriazole $(\mathbf{6 c})$ in $70 \%$ yield.

4,6-dibromobenzotriazole (7c) (see Scheme 5) was obtained in $79 \%$ yield from 3,5-dibromo-ophenylenediamine $\mathbf{( 7 b}$, which was prepared by reduction of commercially available 2,4-dibromo-6nitroaniline (7) with $\mathrm{SnCl}_{2}$ in $\mathrm{EtOH}^{53}$

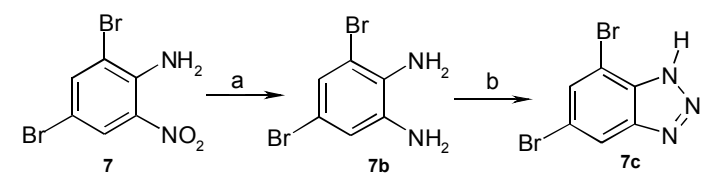

(a) $\mathrm{SnCl}_{2}, \mathrm{AcOH}, \mathrm{EtOH}$, reflux;

(b) $\mathrm{NaNO}_{2}, \mathrm{AcOH}$ or $\mathrm{HCl}, 0^{\circ} \mathrm{C}$;

\section{Scheme 5}

The preparation of 5,6-dibromobenzotriazole (8c, see Scheme 6) was based on an earlier report, ${ }^{39}$ in which o-phenylenediamine (1) was tosylated to enable subsequent selective bromination, leading to formation of its 4,5-dibromo congener (8a). Removal of blocking groups gave 4,5-dibromo-ophenylenediamine $(\mathbf{8 b})$, ring closure of which led to 5,6-dibromobenzotriazole (8c) in $86 \%$ yield.

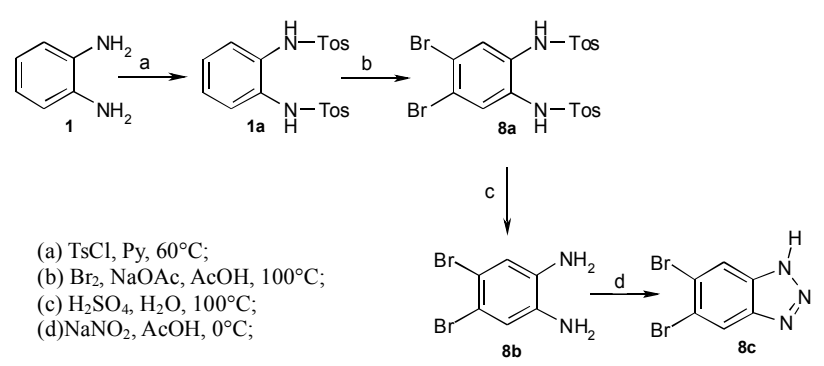

Scheme 6

The synthesis of 4,5,6-tribromobenzotriazole (9c) (Scheme 7), starting from 1,2,3-tribromo-5nitrobenzene (9), involved nitration of the latter with $\mathrm{HNO}_{3} / \mathrm{H}_{2} \mathrm{SO}_{4}$ to yield, quantitatively, 1,2,3tribromo-5,6-dinitrobenzene (9a), reduction of which with $\mathrm{SnCl}_{2}$ in $\mathrm{HCl}$ for 1.5 hours gave the appropriate diamine $(\mathbf{9 b})$. 


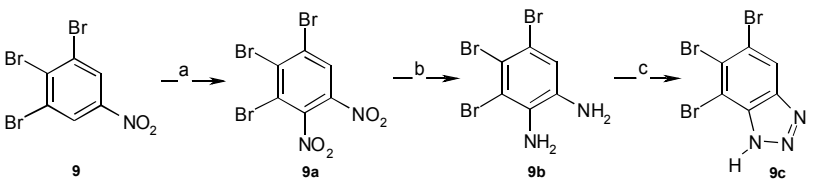

(a) $\mathrm{HNO}_{3}, \mathrm{H}_{2} \mathrm{SO}_{4}, 100^{\circ} \mathrm{C}$;

(b) $\mathrm{SnCl}_{2}, \mathrm{HCl}$;

(c) $\mathrm{NaNO}_{2}, \mathrm{AcOH}$

\section{Scheme 7}

It was noted that treatment of $\mathbf{9 a}$ with iron powder $^{54}$ in $\mathrm{HCl}$ led to reduction of only one nitro group. Ring closure of 2,3,4-tribromo-o-phenylenediamine (9b) led to 4,5,6-tribromobenzotriazole (9c) in $83 \%$ yield.

Physico-chemical properties. The aqueous solubility at neutral $\mathrm{pH}$ of the brominated $\mathrm{Bt}$ derivatives decreases with the number of $\mathrm{Br}$ atoms attached to the benzene ring, the values being significantly modulated by the location of the $\mathrm{Br}$ atoms. Generally $\mathrm{C}(4) / \mathrm{C}(7)$-substituted derivatives are much more soluble than their $\mathrm{C}(5) / \mathrm{C}(6)$ counterparts, which carry the same number of $\mathrm{Br}$ atoms. In consequence 4,7- $\mathrm{Br}_{2} \mathrm{Bt}$ and 4,5,7- $\mathrm{Br}_{3} \mathrm{Bt}$ dissolve at a higher concentration, while solubilities of $\mathrm{TBBt}, 4,5,6-\mathrm{Br}_{3} \mathrm{Bt}$, and other di-bromo derivatives are 10-100 times lower. Interestingly, the solubility of TBBt is almost four-fold higher than that of less brominated 4,5,6- $\mathrm{Br}_{3} \mathrm{Bt}$.

Ionic equilibria. Experimental values of $\mathrm{pK}_{\mathrm{a}}$ for dissociation of the triazole proton in aqueous medium demonstrate that each $\mathrm{Br}$ atom attached to the benzene ring increases the acidity of the compound (Table 1), but the final effect depends on the pattern of substitution. The results obtained with the aid of SPARC server ${ }^{55}$ clearly show that the effect of bromination on $\mathrm{pK}_{\mathrm{a}}$ for dissociation of the triazole proton is underestimated (see Figure 1A). However the regression statistic is acceptable, but with no visible changes in $\mathrm{pK}_{\mathrm{a}}$ related to variation in location of bromine atoms. The latter stimulated us to perform a multidimensional regression analysis, which revealed that the effect of attachment of bromine atoms is almost additive, but there are two pairs of equivalent locations, $\mathrm{C}(4), \mathrm{C}(7)$ and $\mathrm{C}(5), \mathrm{C}(6)$ (Figure 1B). This indicates that each bromine atom attached at the peripheral $\mathrm{C}(4)$ or $\mathrm{C}(7)$ decreases $\mathrm{pK}_{\mathrm{a}}$ by the same value $1.10( \pm 0.04)$, and those attached at the central $\mathrm{C}(5)$ or $\mathrm{C}(6)$ by 0.57 $( \pm 0.04)$. It should be noted that $\mathrm{pK}_{\mathrm{a}}$ of the parent Bt diverts from the regression line. The expected value 
of 8.12 differs significantly from experimental values, reported as $8.56,{ }^{32} 8.67^{56}$ and $8.38 .^{34}$ This deviation from the additivity scheme indicates that solvation of the parent Bt differs quantitatively from its brominated derivatives.

\section{Figure 1}

The low aqueous solubility of the neutral form of TBBt also makes $\mathrm{pK}_{\mathrm{a}}$ measurements difficult, since a high quality low-pH UV spectrum could not be recorded. In consequence the $\mathrm{pK}_{\mathrm{a}}$ values of $4.87 \pm$ $0.22^{32}$ and $5.1 \pm 0.3^{30}$ were estimated for the same sample, using as reference either the noisy UV spectrum recorded at $\mathrm{pH} 2$, or the spectrum recorded in methanol. An earlier $\mathrm{pK}_{\mathrm{a}}$ was estimated as close to $5 .^{57}$

${ }^{13} \mathrm{C}$ NMR: resonance assignments and protomeric equilibria. For most compounds the ${ }^{13} \mathrm{C} \mathrm{NMR}$ spectra, recorded in anhydrous DMSO, display significant broadening of the resonance lines, with widths exceeding $50 \mathrm{~Hz}$ (see Supplementary Figure 2). By contrast, the resonance lines of 5-BrBt and 5,6- $\mathrm{Br}_{2} \mathrm{Bt}$ are narrow, with widths characteristic for low-mass solutes $(\mathrm{C}(4 \mathrm{a}), \mathrm{C}(7 \mathrm{a}) \sim 10 \mathrm{~Hz}$, $\mathrm{C}(5), \mathrm{C}(6) \sim 2.5 \mathrm{~Hz}, \mathrm{C}(4), \mathrm{C}(7) \sim 10 \mathrm{~Hz})$, and $(\mathrm{C}(4 \mathrm{a}) / \mathrm{C}(7 \mathrm{a}) \sim 10 \mathrm{~Hz}, \mathrm{C}(5) / \mathrm{C}(6) \sim 3 \mathrm{~Hz}, \mathrm{C}(4) / \mathrm{C}(7) \sim 10 \mathrm{~Hz})$ for 5-BrBt and 5,6- $\mathrm{Br}_{2} \mathrm{Bt}$, respectively. The observed significant resonance line broadening clearly must be attributed to a dynamic prototropic equilibrium, since addition of a small amount of water results in significant narrowing of all resonance lines (Supplementary Figure 2, right panels). The most evident effect was previously reported for the parent $\mathrm{Bt}^{32}$ and $\mathrm{TBBt},{ }^{30}$ for which, in anhydrous medium, separate signals of the chemically equivalent $\mathrm{C}(4)$ and $\mathrm{C}(7)$ resonances were observed, due to virtual asymmetry caused by slow exchange between the $\mathrm{N}(1)-\mathrm{H}$ and $\mathrm{N}(3)-\mathrm{H}$ protomers (Scheme 2).

Assignments of individual ${ }^{13} \mathrm{C}$ resonances were supported by quantum mechanical (GIAO) calculations of carbon nuclei shielding, using the HF/6-311G basis set, which was previously found adequate for the parent benzotriazole $(\mathbf{1})^{58,59}$ and a series of its symmetrically substituted derivatives. ${ }^{32}$ For non-halogenated carbons the shielding, averaged according to the assumed 1:1 equilibrium between the N(1)-H and N(3)-H neutral forms, was found significantly correlated with the experimental chemical shift values $\left(\mathrm{R}^{2}=0.92\right.$, see Supplementary Figure 1). Consequently, these shielding values were used to 
help in assignment of ambiguous $\mathrm{C}(4 \mathrm{a}) / \mathrm{C}(7 \mathrm{a})$ and other resonances, denoted by asterisks in Table 2 . The $\mathrm{HF} / 6-311 \mathrm{G}$ basis set was found inadequate for prediction of location of ${ }^{13} \mathrm{C}$ resonances of halogenated carbons.

QM calculations. For each molecule the following thermodynamic properties were estimated: (a) Free energy of proton dissociation, $\Delta \mathrm{G}_{\mathrm{diss}}$; (b) Free energy of solvation, $\Delta \mathrm{G}_{\text {solv }}$ (difference between free energy in solution and in vacuo); (c) Protomeric equilibrium between the three possible protonation states of the neutral form (Scheme 2). The overall data are summarized in Table 1.

Free energy of proton dissociation. Free energies of proton dissociation, $\Delta \mathrm{G}_{\mathrm{diss}}$, estimated independently with the aid of ab initio methods (Table 1), almost perfectly reconstruct the order of experimental $\mathrm{pK}_{\mathrm{a}}$ data (Figure $1 \mathrm{C}$ ). For $\mathrm{TBBt}$ the $\mathrm{pK}_{\mathrm{a}}$ value of 4.87 agrees with that predicted by multidimensional regression analysis (Figure $1 \mathrm{~B}, \mathrm{pK}_{\mathrm{a}} 4.78$ ), and also with the calculated free energy of dissociation. Hence the $\mathrm{pK}_{\mathrm{a}}$ of $4.87 \pm 0.22$ for $\mathrm{TBBt}$ is used in all further analyses.

Free energy of solvation. As expected, according to the LCW theory, ${ }^{60}$ the values of $\Delta \mathrm{G}_{\text {solv }}$, determined for both neutral and dissociated molecules, are well correlated with the molecular volume, $\mathrm{V}_{\text {mol. }}$ The noticeable deviations (Figure 2) are directly related to structure-dependent specific hydration. Derivatives with the same number of $\mathrm{Br}$ atoms on the benzene ring differ both in molecular volume and free energy of solvation. In general, derivatives with $\mathrm{Br}$ atoms at vicinal carbons, e.g. 4,5- $\mathrm{Br}_{2} \mathrm{Bt}$, 5,6$\mathrm{Br}_{2} \mathrm{Bt}$ or $4,5,6-\mathrm{Br}_{3} \mathrm{Bt}$, differ in molecular volume from those with an alternative pattern of $\mathrm{Br}$ substitution, such as $4,6-\mathrm{Br}_{2} \mathrm{Bt}, 4,7-\mathrm{Br}_{2} \mathrm{Bt}$ or $4,5,7-\mathrm{Br}_{3} \mathrm{Bt}$. Solvent-related changes in free energy for monoanionic forms are the reverse of those calculated for the neutral forms of the same compounds. This implies that, apart from purely electronic effects, interactions with the aqueous solvent also significantly affect the $\mathrm{pK}_{\mathrm{a}}$ values for dissociation of the triazole proton.

Figure 2

Aqueous solubility. Inspection of $\mathrm{pK}_{\mathrm{a}}$-dependence of solute solubility (see Figure $3 \mathrm{~A}$ ) enables clusterization of ten studied compounds into three well-separated groups differing by the number of 
bromine atoms attached to the peripheral locations of benzene ring (i.e. C4 and C7, see Scheme 2). Within each group the logarithm of solubility is an almost linear function of experimentally determined values of $\mathrm{pK}_{\mathrm{a}}$ for dissociation of triazole proton. This clearly confirms that the ionic equilibrium is the significant factor influencing solubility of halogenated benzotriazoles, although other factors related to the topology of halogenation pattern must be also taken into account.

According to the LCW theory of solvation of hydrophobic molecules in aqueous medium, the free energy of solute-solvent interactions is proportional to the molecular volume of the solute molecule. ${ }^{60}$ Thus, to a first approximation, neglecting differences in free energy of intermolecular interactions in the solid state, the logarithms of experimentally measured aqueous solubility are expected to be a linear function of solute volumes (see Figure 3B).

\section{Figure 3}

The observed marked deviation from an expected common exponential trend between the volume of a molecule and its aqueous solubility indicates that specific solute-solvent interactions cannot be neglected. In principle the effect of a Br atom strongly depends on the substitution pattern, hence the total effect should be regarded as location-specific, indicating that hydration significantly depends on the pattern of $\mathrm{Br}$ substitution, rather than on the number of $\mathrm{Br}$ atoms. The analyzed compounds cluster into two groups, Bt, and three derivatives with both peripheral carbons $(\mathrm{C} 4, \mathrm{C} 7)$ brominated: $4,7-\mathrm{Br}_{2} \mathrm{Bt}$, 4,5,7-Br 3 Bt, TBBt, and 4-BrBt, 5-BrBt, 4,5- $\mathrm{Br}_{2} \mathrm{Bt}, 4,6-\mathrm{Br}_{2} \mathrm{Bt}, 5,6-\mathrm{Br}{ }_{2} \mathrm{Bt}$, 4,5,6- $\mathrm{Br}{ }_{3} \mathrm{Bt}$, within each of which the solubility is strictly correlated with molecular volume. The increased solubility of the three derivatives brominated at 4,7 is strictly related to their decreased $\mathrm{pK}_{\mathrm{a}}$, stabilizing the anionic forms in neutral aqueous solution.

The question arises as to how precisely the ab initio calculations may estimate the specific solutesolvent interactions. In fact, the three-parameter log-regression model, which correctly predicts solubility of all compounds, with only a small deviation for 4-BrBt, is as follows:

$$
\log \left(\mathrm{C}_{\mathrm{w}}\right) \propto(0.19 \pm 0.04) \cdot \mathrm{V}_{\text {mol }}+\mathrm{G}_{\text {diss }} / R T^{\left.-\mathrm{G}_{\text {solv }} \text { (anion) }\right) / R T}
$$


This relation indicates that the general trend of a decrease in solubility with an increase in volume of the solute molecule (indicating hydrophobic solvation) is significantly modulated by specific solutesolvent interactions determined for the monoanionic state of the molecule and, consequently, by its population. As anticipated, ligands that are preferentially solvated, and largely dissociated, display higher solubility (Figure 3C).

Preliminary biological implications. Inhibitory activities against CK2 $\alpha$ were tested using the P81 filter isotopic assay. ${ }^{61}$ The reaction mixture contained $20 \mathrm{mM}$ Tris- $\mathrm{HCl}, \mathrm{pH} 7.5,20 \mathrm{mM} \mathrm{MgCl}, 20 \mu \mathrm{M}$ DTT, $20 \mu \mathrm{M}$ peptide substrate, $0.5 \mathrm{mM} \beta$-glycerol, $0.1 \mathrm{mM}$ EGTA, $10 \mu \mathrm{M}$ ATP (200-300 cpm/pmol), CK2 $\alpha$ $(0.4 \mu \mathrm{g} / \mu \mathrm{l})$ and $50 \mu \mathrm{M}$ tested compound. The estimated levels of reduction of enzymatic activity of CK2 $\alpha$ were found correlated with free ligand solubilities $\left(R^{2}=0.69\right.$, see Figure 4A) and QM-derived free energies of solvation, corrected for QM-derived energies for proton dissociation (Figure $4 B, R^{2}=0.85$ ). It is worth noting that the last correlation successfully predicts that inhibitory activity of compounds 8c and $9 \mathrm{c}$ is close to that of TBBt, notwithstanding that they differ by the number of halogen atoms attached to the benzene ring. Moreover, these two simple thermodynamic parameters adequately distinguish activity of various isomers carrying the same number of bromine atoms, unequivocally confirming that hydrophobic and electrostatic interactions predominate in inhibitory activities of halogenated benzotriazoles.

Figure 4

\section{CONCLUSIONS}

Physico-chemical properties in aqueous medium were analyzed for all nine possible isomers of benzotriazole brominated on the benzene ring. Both the number and location of halogen atoms were found to substantially modulate the $\mathrm{pK}_{\mathrm{a}}$ for dissociation of the triazole proton. ${ }^{13} \mathrm{C}-\mathrm{NMR}$ spectra recorded in anhydrous DMSO demonstrated existence of a protomeric equilibrium, which, according to QM calculations, occurs between the $\mathrm{N}(1)-\mathrm{H}$ and the $\mathrm{N}(3)-\mathrm{H}$ neutral forms. The number of halogen atoms, and their locations, were found to significantly modulate solubility in aqueous medium. Thus the solvation of halogenated benzotriazoles must be driven by a subtle balance between electrostatic and 
hydrophobic interactions. The variation of solution properties resulting from different patterns of halogenation clearly show that, in drug design studies on halogenated ligands, solvation of their non-bound forms can not be neglected. QM-derived free energies for solvation and proton dissociation were found reasonably good predictors of inhibitory activity.

\footnotetext{
SUPPORTING INFORMATION. Supplementary Figures demonstrating (1) correlation between GIAO-derived ${ }^{13} \mathrm{C}$ shielding and experimentally measured chemical shift and (2) a complete set of NMR

${ }^{13} \mathrm{C}$ spectra. This material is available free of charge via the Internet at http://pubs.acs.org.
}

\section{REFERENCES}

1 Wang, W.; Okada, Y.; Wang, Y.; Okuyama, T. J. Nat. Prod. 2005, 68, 620-622.

2 Pauletti, P. M.; Cintra, L. S.; Braguine, C. G.; da Silva Filho, A. A.; Silva, M. L.; Cunha, W. R.; Januário, A. H. Mar. Drugs 2010, 8, 1526-1549.

3 Hernandes, M. Z.; Cavalcanti, S. M. T.; Moreira, D. R. M.; Azevedo Junior, W. F.; Leite, A. C. L. Curr. Drug Targets 2010, 11, 303-314.

4 Lu Y.; Wang Y.; Zhu W. Phys. Chem. Chem. Phys. 2010, 12, 4543-4551.

5 http://www.rcsb.org

6 Voth, A. R.; Ho, P. S. Curr. Top. Med. Chem. 2007, 7, 1336-1348.

7 Parisini, E.; Metrangolo, P.; Pilati, T.; Resnati, G.; Terraneo, G. Chem. Soc. Rev. 2011, 40, $2267-$ 2278.

8 Metrangolo, P.; Meyer, F.; Pilati, T.; Resnati, G.; Terraneo, G. Angew. Chem. Int. Edit. 2008, 47, 6114-6127.

9 Metrangolo, P.; Resnati, G. Science 2008, 321, 918-919. 
10 Chudzinski, M. G.; Taylor, M. S. J. Org. Chem. 2012, 77, 3483-3491.

11 Sarwar, M. G.; Dragisic, B.; Salsberg, L. J.; Gouliaras, C.; Taylor, M. S. J. Am. Chem. Soc. 2010, 132, 1646-1653.

12 Lu, Y.; Li, H.; Zhu, X.; Liu, H.; Zhu, W. Int. J. Quantum Chem. 2011, 112, 1421-1430.

13 Mugnaini, V.; Punta, C.; Liantonio, R.; Metrangolo, P.; Recupero, F.; Resnati, G.; Pedulli, G.F.; Lucarini, M. Tetrahedron Lett. 2006, 47, 3265-3269.

14 Glaser, R., Chen, N.; Wu, H.; Knotts, N.; Kaupp, M. J. Am. Chem. Soc. 2004, 126, 4412-4419.

15 Hauchecorne, D.; van der Veken, B. J.; Moiana, A.; Herrebout, W. Chem. Phys. 2010, 374, 3036.

16 Bertsev, V. V.; Golubev N. S.; Shchepkin, D. N. Opt. Spektrosk. 1976, 40, 951-953.

17 Lu, Y.; Li, H.; Zhu, X.; Zhu, W.; Liu, H. J. Phys. Chem. A 2011, 115, 4467-4475.

18 Auffinger, P.; Hays, F. A.; Westhof, E.; Ho, P. S. P. Natl. Acad. Sci. USA 2004, 101, 1678916794.

19 Voth, A. R.; Hays, F. A.; Ho, P. S. P. Natl. Acad. Sci. USA 2007, 104, 6188-6193.

20 Carter, M; Ho, P. S. Cryst. Growth Des. 2011, 11, 5087-5095.

21 Kraut, D. A.; Sigala, P. A.; Fenn, T. D.; Herschlag, D. P. Natl. Acad. Sci. USA 2010, 107, 19601965.

22 Hardegger, L. A.; Kuhn, B.; Spinnler, B.; Anselm, L.; Ecabert, R.; Stihle, M.; Gsell, B.; Thoma, R.; Diez, J.; Benz, J.; Plancher, J. M.; Hartmann, G.; Isshiki, Y.; Morikami, K.; Shimma, N.; Haap, W.; Banner, D. W.; Diederich, F. ChemMedChem 2011, 6, 2048-2054.

23 Eckenhoff, R. G.; Johansson, J. S. Pharmacol. Rev. 1997, 49, 343-361.

24 Liu, R.; Loll, P. J.; Eckenhoff, R. G. FASEB J. 2005, 19, 567-576.

25 Pop, S. M.; Gupta, N.; Raza, A. S.; Ragsdale, S. W. J. Biol. Chem. 2006, 281, 26382-26390 
26 Memic, A.; Spaller, M. R. ChemBioChem 2008, 9, 2793-2795.

27 Szyszka, R.; Grankowski, N.; Felczak, K.; Shugar, D. Biochem. Bioph. Res. Co. 1995, 208, 418424.

28 Zień, P.; Bretner, M.; Zastapiło, K.; Szyszka, R.; Shugar, D. Biochem. Bioph. Res. Co. 2003, 306, 129-133.

29 Sarno, S.; Papinutto, E.; Franchin, C.; Bain, J.; Elliott, M.; Meggio, F.; Kazimierczuk, Z.; Orzesko, A.; Zanotti, G.; Battistutta, R.; Pinna, L. A. Curr. Top. Med. Chem. 2011, 11, 13401351.

30 Wąsik, R.; Łebska, M.; Felczak, K.; Poznański, J.; Shugar, D. J. Phys. Chem. B 2010, 114, 10601-10611.

31 De Moliner, E.; Brown, N. R.; Johnson, L. N. Eur. J. Biochem. 2003, 270, 1-8.

32 Poznański, J.; Najda, A.; Bretner, M.; Shugar, D. J. Phys. Chem. A 2007, 111, 6501-6509.

33 Borowski, P.; Deinert, J.; Schalinski, S.; Bretner, M.; Ginalski, K.; Kulikowski, T.; Shugar, D. Eur. J. Biochem. 2003, 270, 1645-1653.

34 Hansen, L. D.; West, B. D.; Baca, E. J.; Blank, C. L. J. Am. Chem. Soc. 1978, 90, 6588-6592.

35 Hwang, J. S.; Schilf, R.; Drach, J. C.; Townsend, L. B.; Bogner, E. Antimicrob. Agents Ch. 2009, $53,5095-5101$.

36 Wiley, R. H.; Hussung, K. F. J. Am. Chem. Soc. 1957, 79, 4395-4400.

37 Pilgram, K.; Zupan, M.; Skiles, R. J. Heterocyclic Chem. 1970, 7, 629-633.

38 Gershon, H.; Clarke, D. D.; Gershon, M. Monatsh. Chem. 1994, 125, 723-730.

39 Cheeseman, G. W. H. J. Chem. Soc. 1962, 1171-1176 
40 Cobas, C.; Cruces, J.; Sardina, F.J. MestRe-C 2.3a, Magnetic Resonance Companion NMR Data Processing Program. Departamento de Qu1'mica Orga'nica, Facultad de Quimica, Universidad de Santiago de Compostela, 1706 Santiago de Compostela Spain.

41 Marquardt, D. W. J. Soc. Ind. Appl. Math. 1963, 11, 431-441.

42 Williams, T.; Kelley, C. Gnuplot 2004 Version 4.0, http://www.ucc.ie/gnuplot.

43 Ratnikov, M. O.; Lipilin, D. L.; Churakov, A.; Strelenko M., Yu, A.; Tartakovsky, V. A. Org. Lett. 2002, 4, 3227-3229.

44 Vagin, S.; Frickenschmidt, A.; Kammerer, B.; Hanack, M. Eur. J. Org. Chem. 2005, 15, 32713278.

45 Jackson, C. L.; Fiske, A. H. Amer. Chem. J. 1916, 53, 148-154.

46 Schmidt, M. W.; Baldridge, K. K.; Boatz, J. A.; Elbert, S. T.; Gordon, M. S.; Jensen, J. J.; Koseki, S.; Matsunaga, N.; Nguyen, K. A.; Su, S. Windus, T. L.; Dupuis, M.; Montgomery, J. A. J. Comput. Chem. 1993, 14, 1347-1363.

47 Battistutta, R.; De Moliner, E.; Sarno, S.; Zanotti, G.; Pinna, L. A. Protein Sci. 2001, 10, 2200 2206.

48 Tomasi, J.; Cammi, R.; Mennucci, B. Int. J. Quantum Chem. 1999, 75, 767-783.

49 Tawa, G. J.; Topol, I. A.; Burt, S. K.; Caldwell, R. A.; Rashin, A. A. J. Chem. Phys. 1998, 109, $4852-4863$.

50 Pascual-Ahuir, J. L.; Silla, E.; Tomasi, J.; Bonaccorsi, R. J. Comput. Chem. 1987, 8, 778-787.

51 Tsubata, Y.; Suzuki, T.; Miyashi, T.; Miyashita, Y. J. Org. Chem. 1992, 57, 6749-6755.

52 Edelmann, M. J.; Raimundo, J. M.; Utesch, N. F.; Diederich, F. Helv. Chim. Acta 2002, 85, 2195-2213. 
53 Rangarajan, M.; Kim, J. S.; Sim, S. P.; Liu, A.; Liu, L. F.; La Voie, E. J. Bioorgan. Med. Chem. 2000, $8,2591-2600$.

54 Youngblood, W. J. J. Org. Chem. 2006, 71, 3345-3356.

55 Hilal, S.; Karickhoff, S. W.; Carreira, L. A. Quant. Struct-Act. Rel. 1995, 14, 348-355.

56 Wiley, R. H.; Hussung, K. H.; Moffat, J. J. Am. Chem. Soc. 1955, 77, 5105-5108.

57 Zien, P.; Duncan, J. S.; Skierski, J.; Bretner, M.; Litchfield, D. W.; Shugar, D.. Biochim. Biophys. Acta 2005, 1754, 271-280.

58 Schilf, W.; Stefaniak, L.; Witanowski, M.; Webb, G. A. Magn. Reson. Chem. 1985, 23, 181-184.

59 Wiench, J. W.; Stefaniak, L.; Barszczewicz, A.; Webb, G. A. J. Mol. Struct. 1994, 327, 321-326.

60 Lum, K.; Chandler, D.; Weeks, J. D. J. Phys. Chem. B 1999, 103, 4570-4577.

61 Olsen, B.; Rasmussen, T.; Niefind, K.; Issinger, O. G. Mol. Cell. Biochem. 2008, 316, 37-47. 
Table 1. Experimental values for triazole proton dissociation $\left(\mathrm{pK}_{\mathrm{a}}\right)$ of bromo-benzotriazoles, and aqueous solubility $\left(\mathrm{C}_{\mathrm{w}}\right)$. Included also are molar mass and number of $\mathrm{Br}$ atoms $(0,1$ or 2$)$ attached to the peripherial $\left(\mathrm{n}_{4,7}\right)$ and central $\left(\mathrm{n}_{5,6}\right)$ carbons of the benzene ring, molecular volumes $\left(\mathrm{V}_{\text {mol }}\right)$ of neutral and anionic forms of brominated $\mathrm{Bt}$ derivatives, ab initio derived free energies of proton dissociation $\left(\Delta \mathrm{G}_{\mathrm{diss}}\right)$, free energies of solvation of both forms $\left(\Delta \mathrm{G}_{\mathrm{solv}}(\right.$ neutral $), \Delta \mathrm{G}_{\mathrm{solv}}($ anion $\left.)\right)$, and relative free energies of the three possible protomers of the neutral forms $\left(\Delta \mathrm{G}_{1}, \Delta \mathrm{G}_{2}, \Delta \mathrm{G}_{3}\right)$.

\begin{tabular}{|c|c|c|c|c|c|c|c|c|c|c|c|c|c|}
\hline \multirow{2}{*}{$\begin{array}{l}\text { Compound } \\
\text { Bt }\end{array}$} & \multirow{2}{*}{\begin{tabular}{|c|}
$\mathrm{M}_{\mathrm{w}}$ \\
119.1 \\
\end{tabular}} & \multirow{2}{*}{$\begin{array}{c}\mathrm{n}_{4,7} \\
0\end{array}$} & \multirow{2}{*}{\begin{tabular}{|c|}
$\mathrm{n}_{5,6}$ \\
0
\end{tabular}} & \multirow{2}{*}{$\begin{array}{l}\mathrm{pK}_{\mathrm{a}} \\
8.56\end{array}$} & \multirow{2}{*}{$\begin{array}{c}\mathrm{C}_{\mathrm{w}}[\mathrm{M}] \\
1.96 \cdot 10^{-1}\end{array}$} & \multicolumn{2}{|c|}{$\mathrm{V}_{\mathrm{mol}}\left[\AA^{3}\right]$} & $\begin{array}{c}\Delta \mathrm{G}_{\mathrm{diss}} \\
{[\mathrm{kcal} / \mathrm{mol}]}\end{array}$ & \multicolumn{2}{|c|}{$\Delta \mathrm{G}_{\text {solv }}[\mathrm{kcal} / \mathrm{mol}]$} & \multicolumn{3}{|c|}{$\begin{array}{ccc}\Delta \mathrm{G}_{1} \quad \Delta \mathrm{G}_{2} \quad \Delta \mathrm{G}_{3} \\
{[\mathrm{kcal} / \mathrm{mol}]}\end{array}$} \\
\hline & & & & & & 130.3 & 127.1 & 59.5 & -3.1 & -59.9 & 0.00 & 5.40 & 0.03 \\
\hline 4-BrBt (3c) & 198.0 & 1 & 0 & 7.08 & $3.87 \cdot 10^{-3}$ & 154.1 & 151.1 & 56.7 & -1.0 & -53.3 & 0.45 & 5.75 & 0.00 \\
\hline $5-B r B t(5 c)$ & 198.0 & 0 & 1 & 7.55 & $2.77 \cdot 10^{-3}$ & 154.0 & 151.3 & 58.1 & -1.8 & -50.7 & 0.65 & 5.87 & 0.00 \\
\hline $4,5-\mathrm{Br}_{2} \mathrm{Bt}(6 \mathrm{c})$ & 276.9 & 1 & 1 & 6.49 & $4.99 \cdot 10^{-4}$ & 175.2 & 172.1 & 54.3 & -1.9 & -46.8 & 0.70 & 4.99 & 0.00 \\
\hline $4,6-\mathrm{Br}_{2} \mathrm{Bt}(7 \mathrm{c})$ & 276.9 & 1 & 1 & 6.38 & $2.34 \cdot 10^{-4}$ & 178.0 & 174.7 & 54.2 & -0.6 & -45.5 & 0.09 & 5.82 & 0.00 \\
\hline $4,7-\mathrm{Br}_{2} \mathrm{Bt}(4 \mathrm{c})$ & 276.9 & 2 & 0 & 5.84 & $1.98 \cdot 10^{-3}$ & 177.9 & 174.9 & 53.4 & 2.1 & -48.0 & 0.00 & 4.06 & 0.06 \\
\hline $5,6-\mathrm{Br}_{2} \mathrm{Bt}(8 \mathrm{c})$ & 276.9 & 0 & 2 & 6.93 & $2.31 \cdot 10^{-4}$ & 175.2 & 172.4 & 55.8 & -0.4 & -44.4 & 0.06 & 4.85 & 0.00 \\
\hline $4,5,6-\mathrm{Br}_{3} \mathrm{Bt}(9 \mathrm{c})$ & 355.8 & 1 & 2 & 5.91 & $6.23 \cdot 10^{-5}$ & 195.6 & 192.8 & 52.3 & 0.0 & -40.9 & 0.00 & 4.00 & 0.01 \\
\hline $4,5,7-\mathrm{Br}_{3} \mathrm{Bt}$ & 355.8 & 2 & 1 & 5.38 & $1.04 \cdot 10^{-3}$ & 198.7 & 195.9 & 52.2 & 3.7 & -41.9 & 0.00 & 5.51 & 0.05 \\
\hline TBBt & 434.7 & 2 & 2 & 4.78 & $2.18 \cdot 10^{-4}$ & 216.1 & 213.0 & 49.7 & 5.3 & -38.0 & 0.00 & 5.58 & 0.03 \\
\hline
\end{tabular}


Table 2. Assignments of resonance lines in the ${ }^{13} \mathrm{C}$ spectra of brominated benzotriazoles recorded in $\mathrm{DMSO} / \mathrm{H}_{2} \mathrm{O}$ (99:1). Assignments within the potentially equivalent $\mathrm{C} 4 \mathrm{a} / \mathrm{C} 7 \mathrm{a}, \mathrm{C} 4 / \mathrm{C} 7$ and $\mathrm{C} 5 / \mathrm{C} 6$ resonance pairs (see Scheme 2), denoted by an asterisk, were based on GIAO-derived ${ }^{13} \mathrm{C}$ magnetic shielding parameters (see Supplementary Figure 2 for general correlation between experimental and theoretical data).

\begin{tabular}{|c|c|c|c|c|c|c|c|c|c|c|c|c|}
\hline \multirow{2}{*}{ Compound } & \multicolumn{12}{|c|}{${ }^{13} \mathrm{C}$ chemical shifts $[\mathrm{ppm}]$ and (in brackets) resonance line widths $[\mathrm{Hz}]$} \\
\hline & \multicolumn{2}{|c|}{$\mathrm{C}(4 \mathrm{a})$} & \multicolumn{2}{|c|}{$C(7 a)$} & \multicolumn{2}{|c|}{$C(4)$} & \multicolumn{2}{|c|}{$C(7)$} & \multicolumn{2}{|c|}{$C(5)$} & \multicolumn{2}{|c|}{$C(6)$} \\
\hline Bt & \multicolumn{4}{|c|}{$138.2(1000)$} & \multicolumn{4}{|c|}{$115.1(507)$} & \multicolumn{4}{|c|}{$125.8(88)$} \\
\hline 4-BrBt (3c) & 140.8 & $(50)$ & 138.0 & $(58)$ & 109.1 & $(145)$ & 113.8 & $(107)$ & $128.5^{*}$ & $(25)$ & $128.3^{*}$ & $(23)$ \\
\hline $5-B r B t(5 c)$ & $139.9^{*}$ & (10) & $137.9^{*}$ & $(10)$ & $117.5^{*}$ & (10) & $117.0^{*}$ & (10) & 118.3 & (3) & 128.5 & (3) \\
\hline $4,5-\mathrm{Br}_{2} \mathrm{Bt}(6 \mathrm{c})$ & $142.0^{*}$ & (44) & $137.5^{*}$ & (58) & 111.3 & (47) & 115.5 & $(38)$ & 121.4 & (26) & 131.3 & $(25)$ \\
\hline $4,6-\mathrm{Br}_{2} \mathrm{Bt}(7 \mathrm{c})$ & $138.7^{*}$ & (237) & $140.7^{*}$ & (265) & 110.9 & (155) & 116.7 & (143) & 130.7 & (43) & 119.9 & $(62)$ \\
\hline $4,7-\mathrm{Br}_{2} \mathrm{Bt}(4 \mathrm{c})$ & \multicolumn{4}{|c|}{$139.8(48)$} & \multicolumn{4}{|c|}{$107.3(43)$} & \multicolumn{4}{|c|}{$129.9(20)$} \\
\hline $5,6-\mathrm{Br}_{2} \mathrm{Bt}(8 \mathrm{c})$ & \multicolumn{4}{|c|}{$139.2(12)$} & \multicolumn{4}{|c|}{$119.8(6)$} & \multicolumn{4}{|c|}{$120.7(3)$} \\
\hline $4,5,6-\mathrm{Br}_{3} \mathrm{Bt}(9 \mathrm{c})$ & $141.6^{*}$ & (62) & $137.9^{*}$ & (93) & 113.2 & (78) & 118.8 & $(60)$ & $124.2^{*}$ & $(35)$ & $122.5^{*}$ & (34) \\
\hline $4,5,7-\mathrm{Br}_{3} \mathrm{Bt}$ & $140.6^{*}$ & (5) & $139.6^{*}$ & (5) & $110.1^{*}$ & (4) & $108.8^{*}$ & (4) & 122.9 & (3) & 132.7 & (3) \\
\hline TBBt & \multicolumn{4}{|c|}{$139.0(57)$} & \multicolumn{4}{|c|}{$111.0(57)$} & \multicolumn{4}{|c|}{$124.7(14)$} \\
\hline
\end{tabular}




\section{FIGURE CAPTIONS.}

Figure 1. Correlation of experimental $\mathrm{pK}_{\mathrm{a}}$ values of brominated benzotriazoles with (A) those predicted with the aid of SPARC server (http://archemcalc.com/sparc), (B) values obtained from multilinear regression, based on the number of $\mathrm{Br}$ atoms $(0,1$, or 2$)$ located at $\mathrm{C}(4), \mathrm{C}(7)$ and/or $\mathrm{C}(5), \mathrm{C}(6)$, and $(\mathrm{C})$ the ab initio calculated free energy of dissociation $\left(\Delta \mathrm{G}_{\mathrm{diss}}\right)$ of the triazole proton.

Figure 2. Ab initio calculations of the free energy of solvation $\left(\Delta \mathrm{G}_{\text {solv }}\right)$ of all possible brominated derivatives of benzotriazole, for their neutral $(\circ \circ \circ)$ and ionic $(\bullet \bullet \bullet)$ forms, represented according to LCW theory as a function of solute molecular volume. The small, but noticeable, deviations between derivatives with the same number of $\mathrm{Br}$ atoms (and of similar volume) are ascribed to site-specific hydration, due to variations in accessibility of $\mathrm{Br}$ atoms to the aqueous solvent, and to differences in electron density distribution by the patterns of location of the $\mathrm{Br}$ atoms.

Figure 3. Prediction of solubility $\left(\mathrm{C}_{\mathrm{w}, \exp }\right)$ of brominated benzotriazoles, based (A) on their $\mathrm{pK}_{\mathrm{a}}$ values for dissociation of the triazole proton, (B) on their molecular volumes and (C) on ab initio calculations. The $\mathrm{pK}_{\mathrm{a}}$-dependence clearly distinguished between the effects of halogenation of the benzene ring at the central $(\mathrm{C} 5, \mathrm{C} 6)$ and peripheral $(\mathrm{C} 4, \mathrm{C} 7)$ carbon atoms, while the log-regression model $\left(\mathrm{C}_{\mathrm{w}, \text { calc }}\right)$, which corrects for the effect of uniform hydrophobic solvation (according to LCW theory, proportional to the molecular volume) for the free energies of dissociation and solvation, reasonably well predicts experimental solubility.

Figure 4. Correlation of experimentally determined inhibition of CK2 2 by $50 \mu \mathrm{M}$ solutions of halogenated benzotriazoles with (A) their aqueous solubilities, $\mathrm{C}_{\mathrm{w}, \exp }$ and (B) with QM-derived free energies of solvation, $\Delta \mathrm{G}_{\text {solv }}$, corrected for free energies of dissociation of the triazole proton, $\Delta \mathrm{G}_{\text {solv }}$ 
Figure 1. Correlation of experimental $\mathrm{pK}_{\mathrm{a}}$ values of brominated benzotriazoles with (A) those predicted with the aid of SPARC server (http://archemcalc.com/sparc), (B) values obtained from multilinear regression, based on the number of $\mathrm{Br}$ atoms $(0,1$, or 2$)$ located at $\mathrm{C}(4), \mathrm{C}(7)$ and/or $\mathrm{C}(5), \mathrm{C}(6)$, and $(\mathrm{C})$ the ab initio calculated free energy of dissociation $\left(\Delta \mathrm{G}_{\mathrm{diss}}\right)$ of the triazole proton.
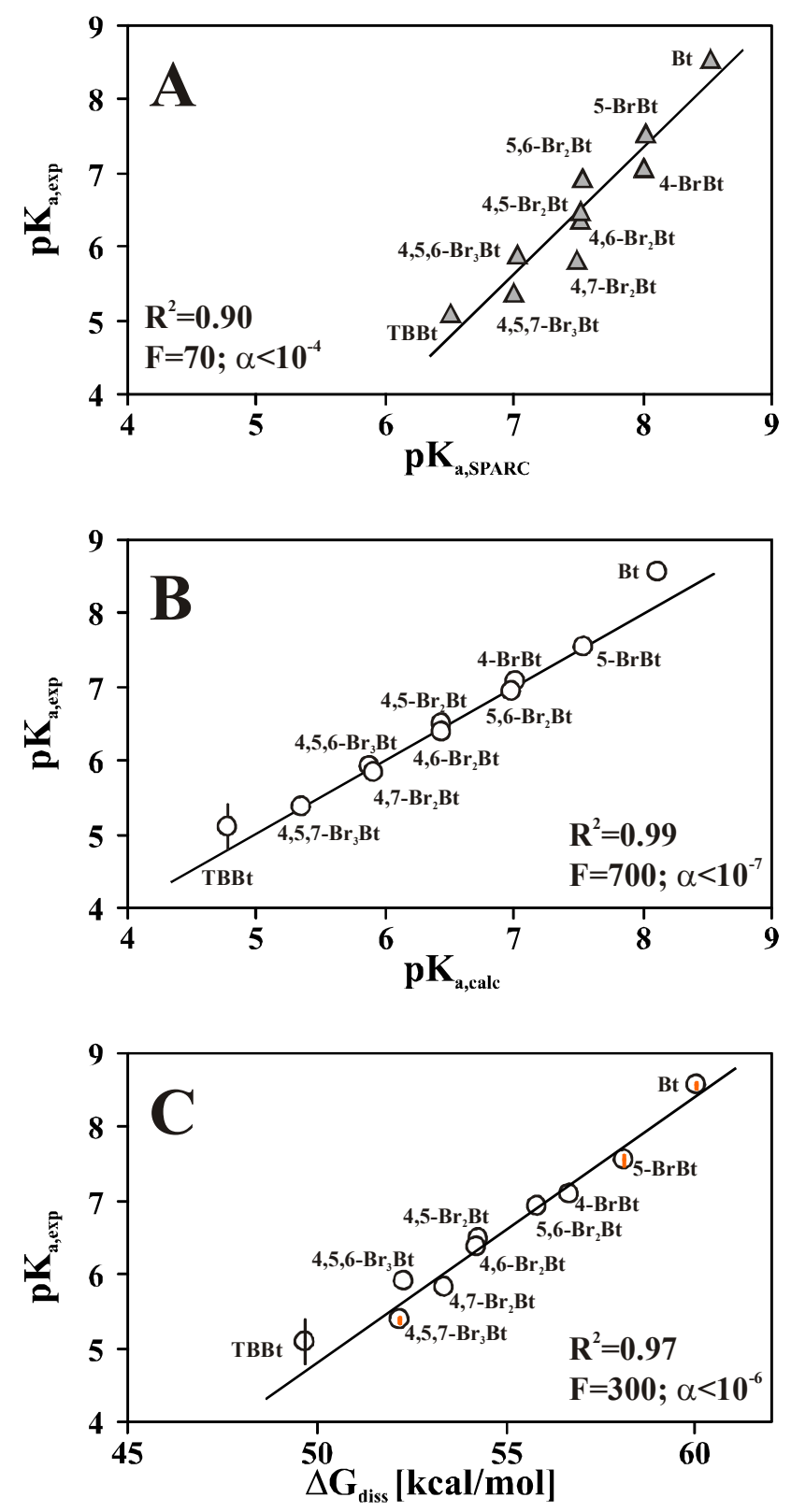
Figure 2. Ab initio calculations of the free energy of solvation $\left(\Delta \mathrm{G}_{\text {solv }}\right)$ of all possible brominated derivatives of benzotriazole, for their neutral $(\circ \circ \circ)$ and ionic $(\bullet \bullet \bullet)$ forms, represented according to LCW theory as a function of solute molecular volume. The small, but noticeable, deviations between derivatives with the same number of $\mathrm{Br}$ atoms (and of similar volume) are ascribed to site-specific hydration, due to variations in accessibility of $\mathrm{Br}$ atoms to the aqueous solvent, and to differences in electron density distribution by the patterns of location of the $\mathrm{Br}$ atoms.

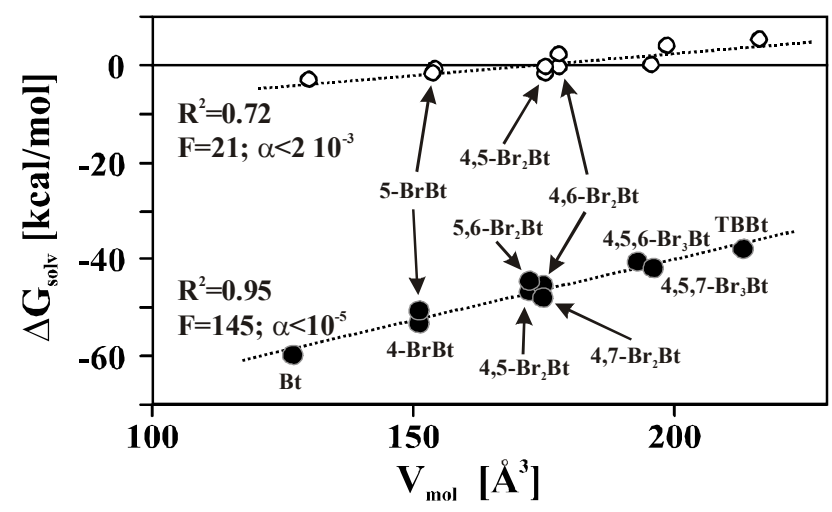


Figure 3. Prediction of solubility $\left(\mathrm{C}_{\mathrm{w}, \mathrm{exp}}\right)$ of brominated benzotriazoles, based $(\mathrm{A})$ on their $\mathrm{pK}_{\mathrm{a}}$ values for dissociation of the triazole proton, (B) on their molecular volumes and (C) on ab initio calculations. The $\mathrm{pK}_{\mathrm{a}}$-dependence clearly distinguished between the effects of halogenation of the benzene ring at the central $(\mathrm{C} 5, \mathrm{C} 6)$ and peripherial $(\mathrm{C} 4, \mathrm{C} 7)$ carbon atoms, while the log-regression model $\left(\mathrm{C}_{\mathrm{w}, \text { calc }}\right)$, which corrects for the effect of uniform hydrophobic solvation (according to LCW theory, proportional to the molecular volume) for the free energies of dissociation and solvation, reasonably well predicts experimental solubility.
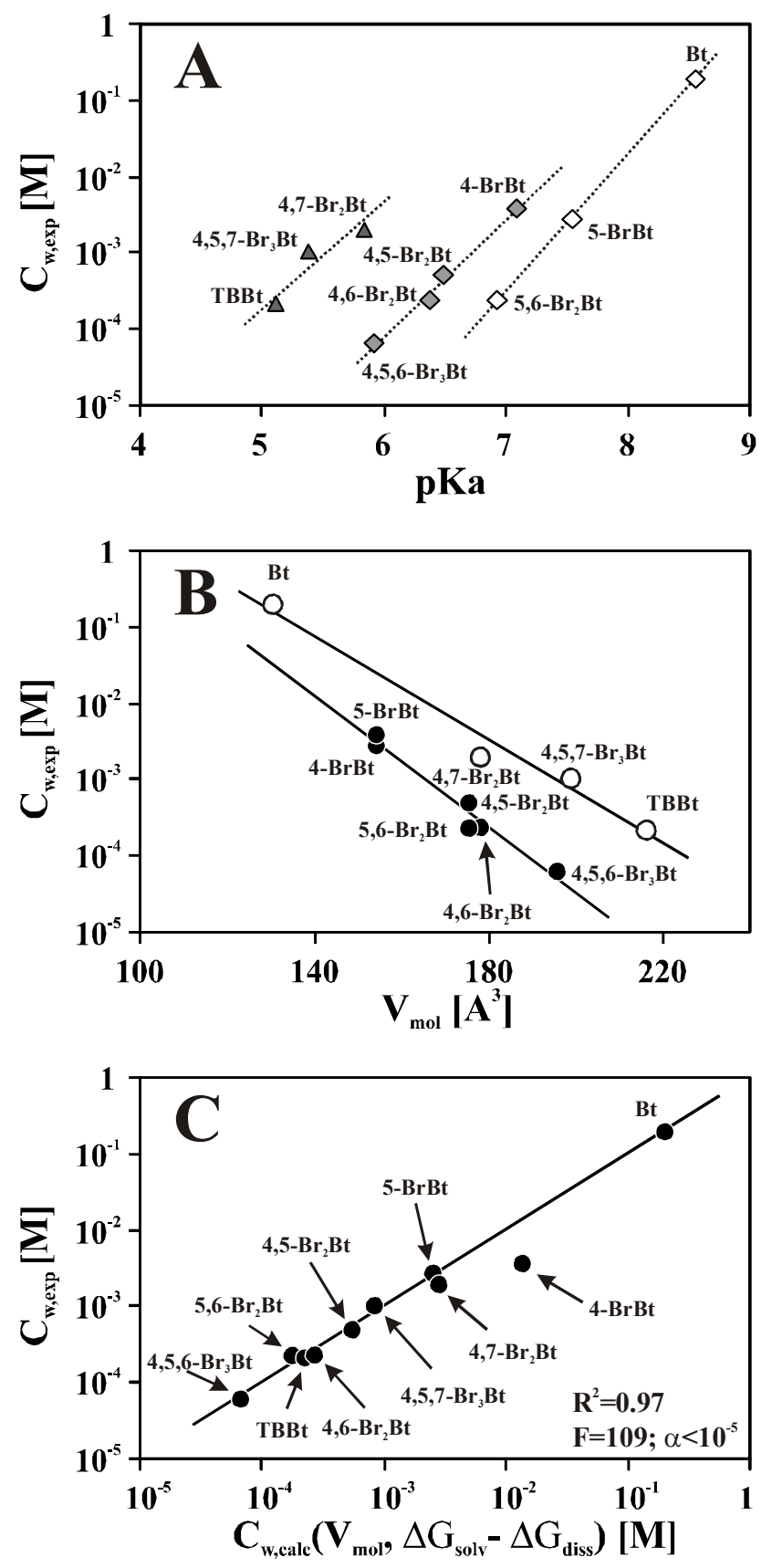
Figure 4. Correlation of experimentally determined inhibition of CK $2 \alpha$ by $50 \mu \mathrm{M}$ solutions of halogenated benzotriazoles with (A) their aqueous solubilities, $\mathrm{C}_{\mathrm{w}, \exp }$ and (B) with QM-derived free energies of solvation, $\Delta \mathrm{G}_{\text {solv }}$, corrected for free energies of dissociation of the triazole proton, $\Delta \mathrm{G}_{\text {solv }}$
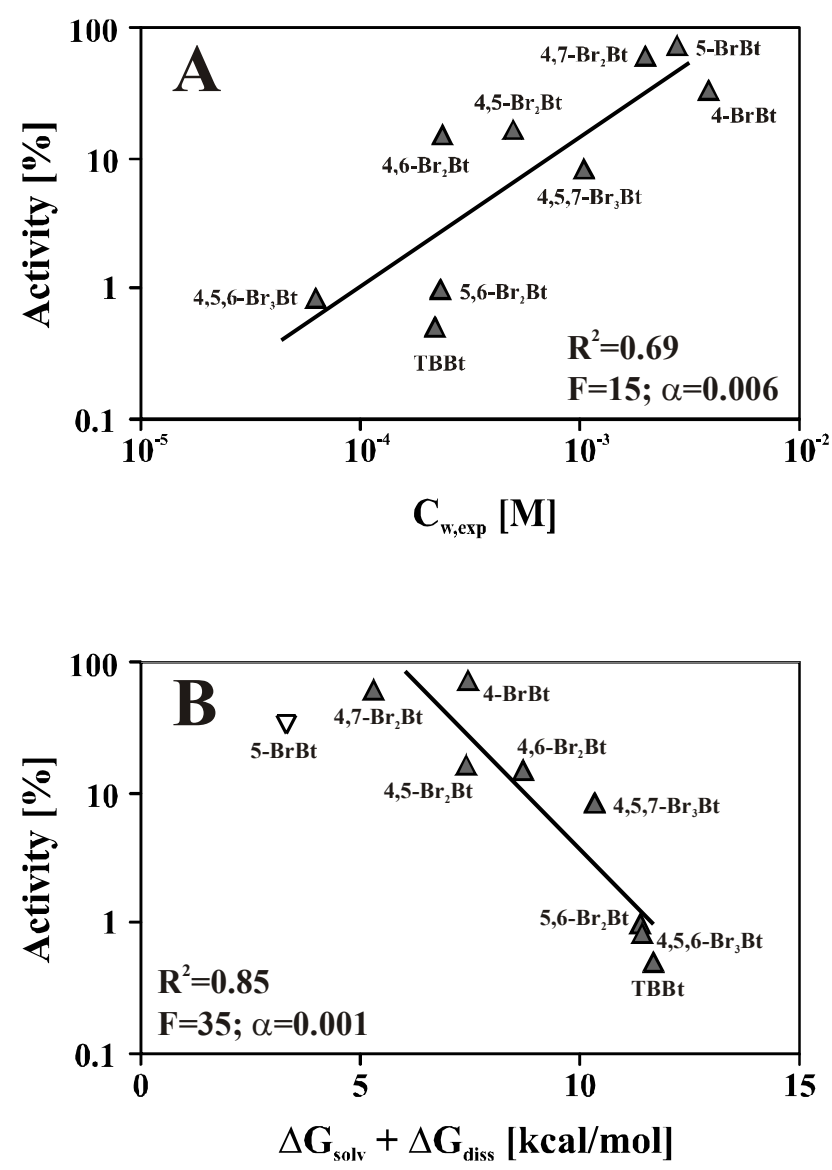
Graphic for Table of Contents

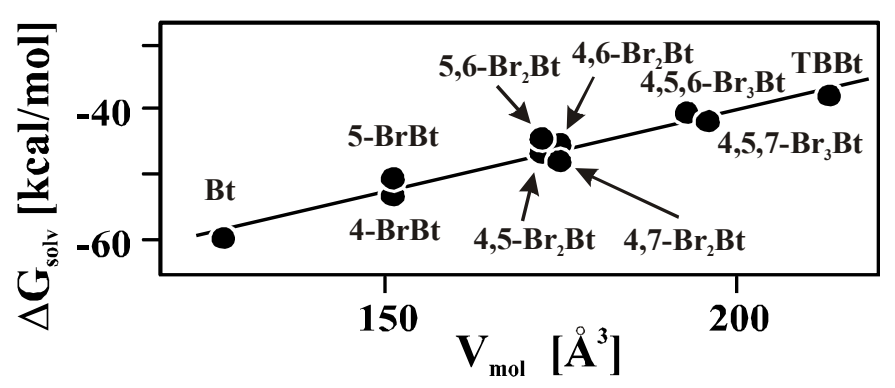

2

4

5

6

7

8

9

10

11

12

13

14

15

16

17

18

19

20

21

22

23

24

25

26

27

28

29

30

31

32

33

34

35

36

37

38

39

40

41

42

43

44

45

46

47

48

49

50

51

52

53

54

55

56

57

58

59

60 